Supporting Information

\title{
Systematic Investigation of Molecular Recognition Ability in FET-Based Chemical Sensors Functionalized with a Mixed
}

\section{Self-Assembled Monolayer System}

Tsukuru Minamiki, ${ }^{*, \dagger, \sharp l}$ Yuki Ichikawa, ${ }^{\dagger, \S, l}$ and Ryoji Kurita ${ }^{*, \dagger,+, \S}$

${ }^{\dagger}$ Biomedical Research Institute, National Institute of Advanced Industrial Science and Technology (AIST), 1-1-1 Higashi, Tsukuba, Ibaraki, 305-8566, Japan.

¿DAILAB, DBT-AIST International Center for Translational and Environmental Research (DAICENTER), National Institute of Advanced Industrial Science and Technology (AIST), Central 541, 1-1-1 Higashi, Tsukuba, Ibaraki, 305-8565, Japan.

${ }^{\S}$ Faculty of Pure and Applied Sciences, University of Tsukuba, 1-1-1 Tennodai, Tsukuba, Ibaraki 3058573, Japan

*Corresponding authors: t.minamiki@aist.go.jp (T.M.); r.kurita@aist.go.jp (R.K.)

'T.M. and Y.I. contributed equally to this work.

\section{Table of Contents}

1. General 1

2. Fabrication of the extended-gate sensing electrode 3

3. Surface characterization of the SAM-modified Au films 3

3. The relationship of drain currents and threshold voltages 4

4. The determination of the apparent equilibrium dissociation constants 4

5. Electrical titrations by using the FET devices 5

7. The $\mathrm{p} K_{\mathrm{a}}$ values of the reagents 25

8. Cycle measurements 26

9. $\mathrm{pH}$ titration 31

10. Estimation of the limit of detection 32

11. References 33 


\section{General.}

Chemicals: All reagents and solvents employed for this study were used as supplied

(Table S1). The pure water was served from a Milli-Q water purification system (18 M $\Omega$ $\mathrm{cm}$ at $\left.25^{\circ} \mathrm{C}\right)$.

Table S1. Chemicals.

\begin{tabular}{|c|c|c|}
\hline Reagents & CAS No. & ${ }^{a}$ Supplier, ${ }^{b}$ code, and ${ }^{c}$ grade \\
\hline Sodium hydroxide & $1310-73-2$ & $\begin{array}{l}{ }^{\mathrm{a}} \text { FUJIFILM Wako Pure Chemical } \\
\text { Corporation, }{ }^{\mathrm{b}} 195-13775,{ }^{\mathrm{c}} 93.0+\%\end{array}$ \\
\hline Methanol & $67-56-1$ & $\begin{array}{l}{ }^{\mathrm{a}} \text { FUJIFILM Wako Pure Chemical } \\
\text { Corporation, }{ }^{\mathrm{b}} 134-01833,{ }^{\mathrm{c}} 99.5+\%\end{array}$ \\
\hline Hydrochloric acid & $7647-01-0$ & $\begin{array}{l}{ }^{\mathrm{a}} \text { FUJIFILM Wako Pure Chemical } \\
\text { Corporation, }{ }^{\mathrm{b}} 087-01076,{ }^{\mathrm{c}} 35.0-37.0 \%\end{array}$ \\
\hline $\begin{array}{l}\text { Cytop (amorphous } \\
\text { perfluoropolymer) }\end{array}$ & - & ${ }^{\mathrm{a}}$ AGC Inc., ${ }^{\mathrm{b}} \mathrm{CTX}-809 \mathrm{SP} 2$ \\
\hline Heptacosafluorotributylamine & $311-89-7$ & ${ }^{\mathrm{a}}$ AGC Inc., ${ }^{\mathrm{b}}$ CT-solv. 180 \\
\hline Sodium chloride & $7647-14-5$ & $\begin{array}{l}{ }^{\mathrm{a}} \text { FUJIFILM Wako Pure Chemical } \\
\text { Corporation, }{ }^{\mathrm{b}} 198-01675,{ }^{\mathrm{c}} 99.0+\%\end{array}$ \\
\hline $\begin{array}{l}\text { 2-[4-(2-Hydroxyethyl)-1- } \\
\text { piperazinyl]ethanesulfonic } \\
\text { acid (HEPES) }\end{array}$ & $7365-45-9$ & $\begin{array}{l}{ }^{a} \text { Dojindo Laboratories, }{ }^{b} \text { GB10, }{ }^{c} \\
99.0+\%\end{array}$ \\
\hline Benzenethiol (BT) & $108-98-5$ & $\begin{array}{l}{ }^{\mathrm{a}} \text { FUJIFILM Wako Pure Chemical } \\
\text { Corporation, }{ }^{\mathrm{b}} 201-01153,{ }^{\mathrm{c}} 95.0+\%\end{array}$ \\
\hline $\begin{array}{l}\text { 4-Mercaptobenzoic acid } \\
\text { (MBA) }\end{array}$ & $1074-36-8$ & $\begin{array}{l}{ }^{\mathrm{a}} \text { Tokyo Chemical Industry Co., Ltd., }{ }^{\mathrm{b}} \\
\text { M1294, }{ }^{\mathrm{c}} 95.0+\%\end{array}$ \\
\hline $\begin{array}{l}\text { Ethylenediamine } \\
\text { dihydrochloride }\end{array}$ & $333-18-6$ & ${ }^{\mathrm{a}}$ Aldrich, ${ }^{\mathrm{b}} 195804-100 \mathrm{G},{ }^{\mathrm{c}} 98 \%$ \\
\hline $\begin{array}{l}\text { 1,4-Diaminobutane } \\
\text { dihydrochloride (Putrescine) }\end{array}$ & $333-93-7$ & $\begin{array}{l}{ }^{\text {a }} \text { Tokyo Chemical Industry Co., Ltd., } \\
\text { D0081, }{ }^{\text {c }} 98+\%\end{array}$ \\
\hline $\begin{array}{l}\text { 1,5-Diaminopentane } \\
\text { dihydrochloride (Cadaverine) }\end{array}$ & $1476-39-7$ & $\begin{array}{l}{ }^{a} \text { Tokyo Chemical Industry Co., Ltd., }{ }^{b} \\
\text { D0099, }{ }^{c} 98+\%\end{array}$ \\
\hline Spermidine Trihydrochloride & $334-50-9$ & ${ }^{\mathrm{a}}$ Aldrich, ${ }^{\mathrm{b}} 85578-1 \mathrm{G},{ }^{\mathrm{c}} 99.5+\%$ \\
\hline Spermine Tetrahydrochloride & $306-67-2$ & $\begin{array}{l}\text { a Sigma, }{ }^{b} \text { S1141-1G, }{ }^{c} \text { BioReagent for } \\
\text { molecular biology }\end{array}$ \\
\hline
\end{tabular}


Instruments: All gold $(\mathrm{Au})$ thin-films were prepared in a clean-room (class 100) at the AIST Nano-Processing Facility (NPF), Tsukuba, Japan.

Table S2. Instruments.

\begin{tabular}{|c|c|c|}
\hline Instruments & ${ }^{a}$ Brands and ${ }^{b}$ types & Conditions \\
\hline $\begin{array}{l}\text { Field-effect transistor } \\
\text { (FET) }\end{array}$ & $\begin{array}{l}\text { a Toshiba Semiconductor } \\
\text { Co., Ltd., }{ }^{\text {b } 2 S K 241 Y ~}\end{array}$ & $\begin{array}{l}V_{\mathrm{DS}}=5 \mathrm{~V}, V_{\mathrm{GS}}=-3-+3 \mathrm{~V}, \\
\text { Step }=0.1 \mathrm{~V} \quad(N-\mathrm{ch} \\
\text { MOSFET })\end{array}$ \\
\hline Sourcemeter equipment & $\begin{array}{l}{ }^{\mathrm{a}} \text { Keithley Instruments, } \\
{ }^{\mathrm{b}} 2636 \mathrm{~B}\end{array}$ & - \\
\hline Contact angle goniometer & $\begin{array}{l}{ }^{\mathrm{a}} \text { Kyowa Interface Science } \\
\text { Co., Ltd., b DMo-501 }\end{array}$ & - \\
\hline $\begin{array}{l}\text { X-ray photoelectron } \\
\text { spectroscopy (XPS) }\end{array}$ & $\begin{array}{l}{ }^{\mathrm{a}} \text { KRATOS Analytical } \\
\text { Ltd., }{ }^{\mathrm{b}} \text { AXIS Nova surface } \\
\text { analysis spectrometer }\end{array}$ & Radiation source: AlKa \\
\hline $\mathrm{pH}$ meter & $\begin{array}{l}{ }^{a} \text { HORIBA, Ltd., }{ }^{b} \text { D-71 } \\
\text { LAQUAact Handheld } \\
\text { Meter }\end{array}$ & - \\
\hline UV/ozone cleaner & $\begin{array}{l}{ }^{\mathrm{a}} \text { SEN LIGHTS, b SSP16- } \\
110\end{array}$ & - \\
\hline $\begin{array}{l}\text { Reactive ion etching } \\
\text { (RIE) equipment }\end{array}$ & ${ }^{\mathrm{a}}$ Samco Inc., ${ }^{\mathrm{b}}$ RIE-200 & $\begin{array}{l}\text { RF: } 150 \mathrm{~W} \text {, Back pressure: } \\
30 \mathrm{~Pa}, \mathrm{O}_{2} \text { flow rate: } 30 \mathrm{sccm}\end{array}$ \\
\hline $\begin{array}{l}\text { Physical vapor deposition } \\
\text { (PVD) equipment }\end{array}$ & $\begin{array}{l}{ }^{\mathrm{a}} \text { Biemtron Co., Ltd., } \\
{ }^{\mathrm{b}} \text { KIS3 }\end{array}$ & $\begin{array}{l}\text { Deposition rate: } 0.2-3.2 \AA / \mathrm{s} \text {, } \\
\text { Back pressure: } 8 \times 10^{-4}- \\
4 \times 10^{-3} \mathrm{~Pa}\end{array}$ \\
\hline Spincoater & 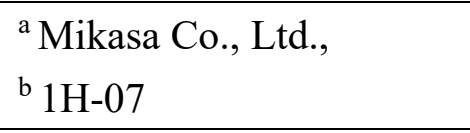 & - \\
\hline Reference electrode & ${ }^{\mathrm{a}} \mathrm{BAS}$, Inc., ${ }^{\mathrm{b}} \mathrm{RE}-1 \mathrm{~B}$ & $\mathrm{Ag} / \mathrm{AgCl}, 3 \mathrm{M} \mathrm{NaCl}$ \\
\hline
\end{tabular}


2. Fabrication of the extended-gate sensing electrode. ${ }^{1}$

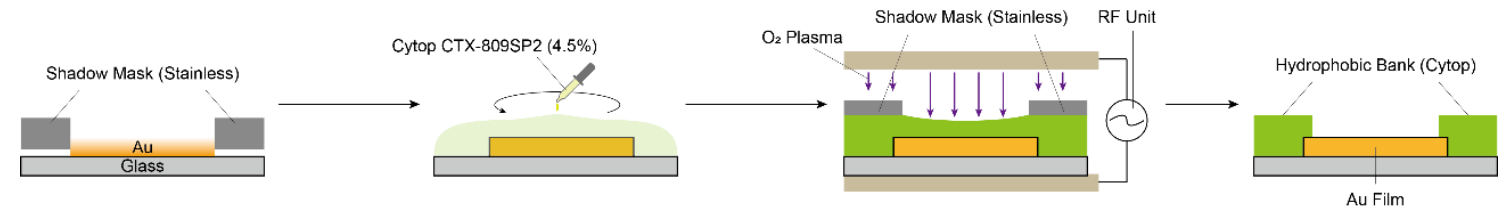

Figure S1. Fabrication process of the Au extended-gate electrode.

\section{Surface characterization of the SAM-modified Au films.}

Contact angle goniometry (CAG) measurements:
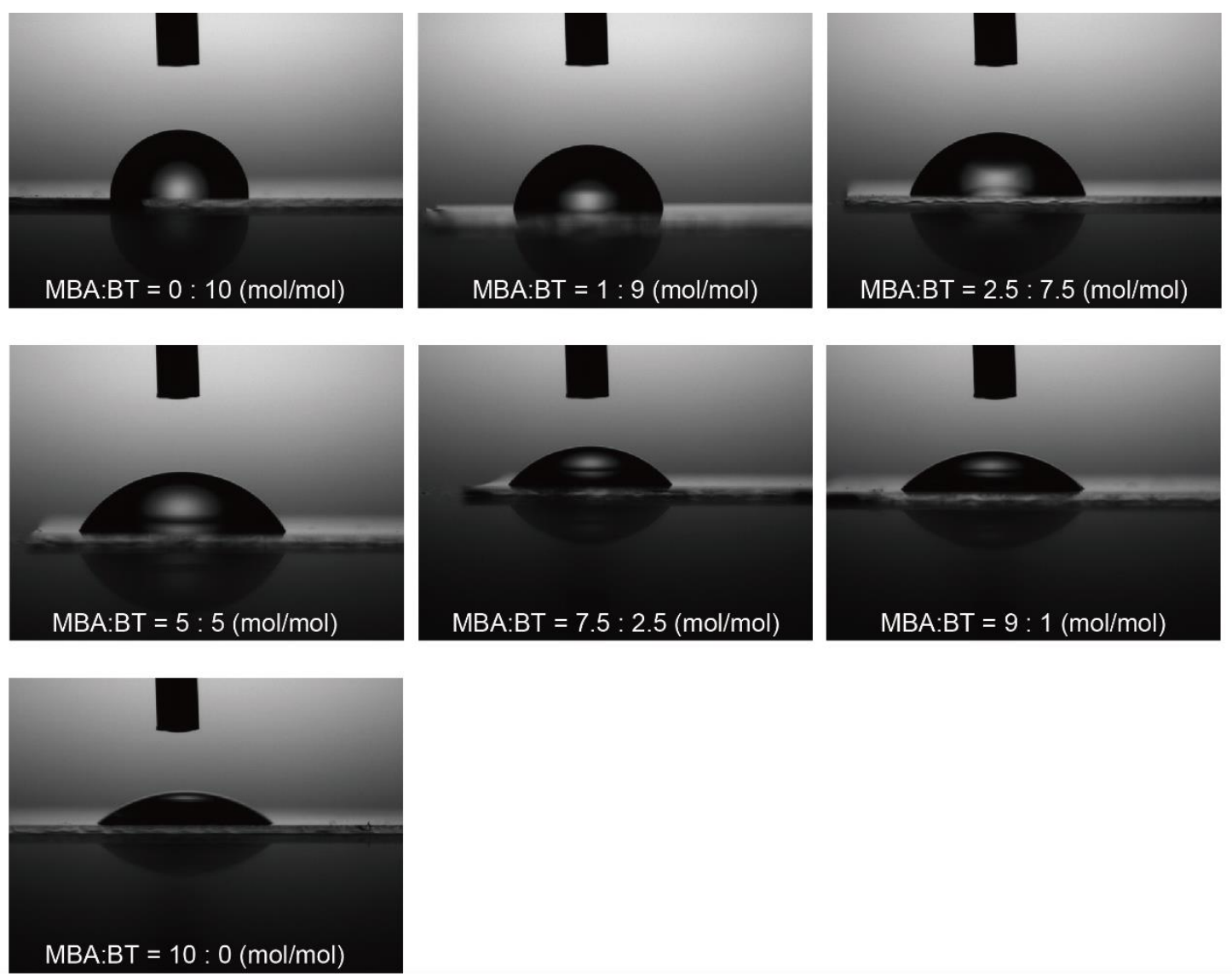

Figure S2. Goniometry images of the water droplet on the Au film modified with the SAMs. 


\section{The relationship of drain currents and threshold voltages.}

To estimate threshold voltage $\left(V_{\mathrm{TH}}\right)$, the following equation was used:

$$
I_{\mathrm{DS}}=\frac{W}{2 L} \mu C\left(V_{\mathrm{GS}}-V_{\mathrm{TH}}\right)^{2}
$$

where $I_{\mathrm{DS}}$ is the drain current, $W$ and $L$ are the channel width and length, $\mu$ is the fieldeffect mobility, $C$ is the capacitance of the gate dielectric, $V_{\mathrm{GS}}$ is the gate voltage, and $V_{\mathrm{TH}}$ is the threshold voltage.

\section{The determination of the apparent equilibrium dissociation constants. ${ }^{2,3}$}

In order to abstract equilibrium dissociation constants, the response curves of the electrical titration isotherm were fit to the Hill-Waud binding model ${ }^{2,3}$ :

$$
V_{\mathrm{TH}}=V_{\mathrm{TH}(\max )} \times \frac{([X])^{n}}{\left(K_{\mathrm{d}}\right)^{n}+([X])^{n}}
$$

where $V_{\mathrm{TH}}$ is the threshold voltage, $V_{\mathrm{TH}(\max )}$ is the maximum threshold voltage when analyte completely saturate the SAM surface, $[X]$ is the analyte concentration, $K_{\mathrm{d}}$ is the apparent equilibrium dissociation constants, and $n$ is the Hill coefficient of cooperativity. Table S3. The calculated Hill coefficient of cooperativity. ${ }^{\mathrm{a}}$

\begin{tabular}{llllll}
\hline & Analyte & & & & \\
\cline { 2 - 6 } SAM & $\begin{array}{l}\text { Ethylene } \\
\text { diamine }\end{array}$ & Putrescine & Cadaverine & Spermidine & Spermine \\
\hline mSAM 10 & 7.6 & 2.4 & 2.3 & 4.1 & ND $^{\mathrm{c}}$ \\
mSAM 50 & 5.0 & 3.8 & $\mathrm{ND}^{\mathrm{b}}$ & 1.9 & 4.7 \\
mSAM 75 & 1.7 & 1.3 & 1.2 & 2.5 & 3.5 \\
MBA-SAM & 0.47 & 0.69 & 0.45 & 0.37 & $\mathrm{ND}^{\mathrm{c}}$ \\
\hline
\end{tabular}

a The calculated Hill coefficients of cooperativity $(n)$ were calculated using the change in threshold voltage upon the addition of each analyte in a HEPES buffer $(100 \mathrm{mM})$ solution with $\mathrm{NaCl}(100 \mathrm{mM})$ at $\mathrm{pH} 7.0$ at $27^{\circ} \mathrm{C}$. ${ }^{\mathrm{b}} \mathrm{ND}$ means not determined because the fitting calculation based on the Hill-Waud model was not converged. ${ }^{\mathrm{c}}$ The Hill coefficients could not be determined owing to the insufficient change in the electrical response. 


\section{Electrical titrations by using the FET devices.}

For the detection of biogenic amines, the extended-gate electrode functionalized with each SAM was immersed in a HEPES buffer $(100 \mathrm{mM})$ solution containing ethylenediamine, cadaverine, putrescine, spermidine, or spermine $(0-2500 \mu \mathrm{M})$ with 100 $\mathrm{mM} \mathrm{NaCl}$ at $27^{\circ} \mathrm{C}$, after which amines were electrically detected by the FET.
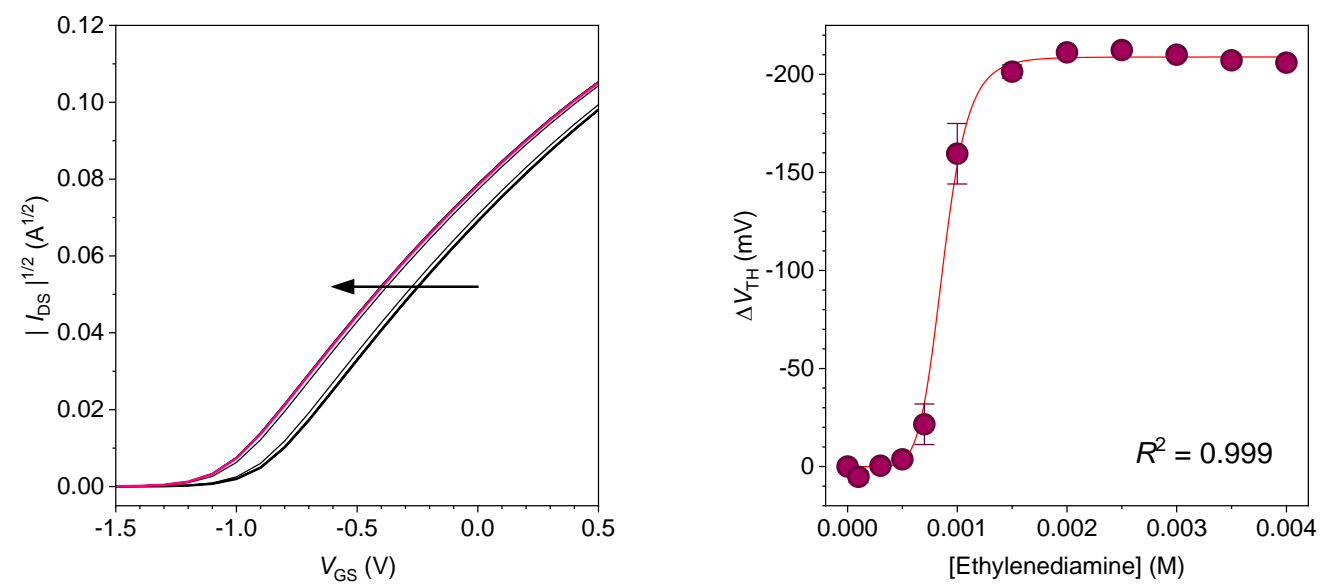

Figure S3. (left) Transfer characteristics of the FET functionalized with the mSAM 10 $([\mathrm{MBA}]=10 \mathrm{~mol} \%)$ upon the addition of ethylenediamine in a HEPES buffer solution $(100 \mathrm{mM})$ with $\mathrm{NaCl}(100 \mathrm{mM})$ at $\mathrm{pH} 7.0$ at $27^{\circ} \mathrm{C}$. [Ethylenediamine] $=0-4000 \mu \mathrm{M}$. (right) Changes in threshold voltage for the FET device by ethylenediamine at various concentrations in a HEPES buffer solution $(100 \mathrm{mM})$ with $\mathrm{NaCl}(100 \mathrm{mM})$ at $\mathrm{pH} 7.0$ at $27^{\circ} \mathrm{C}$. 

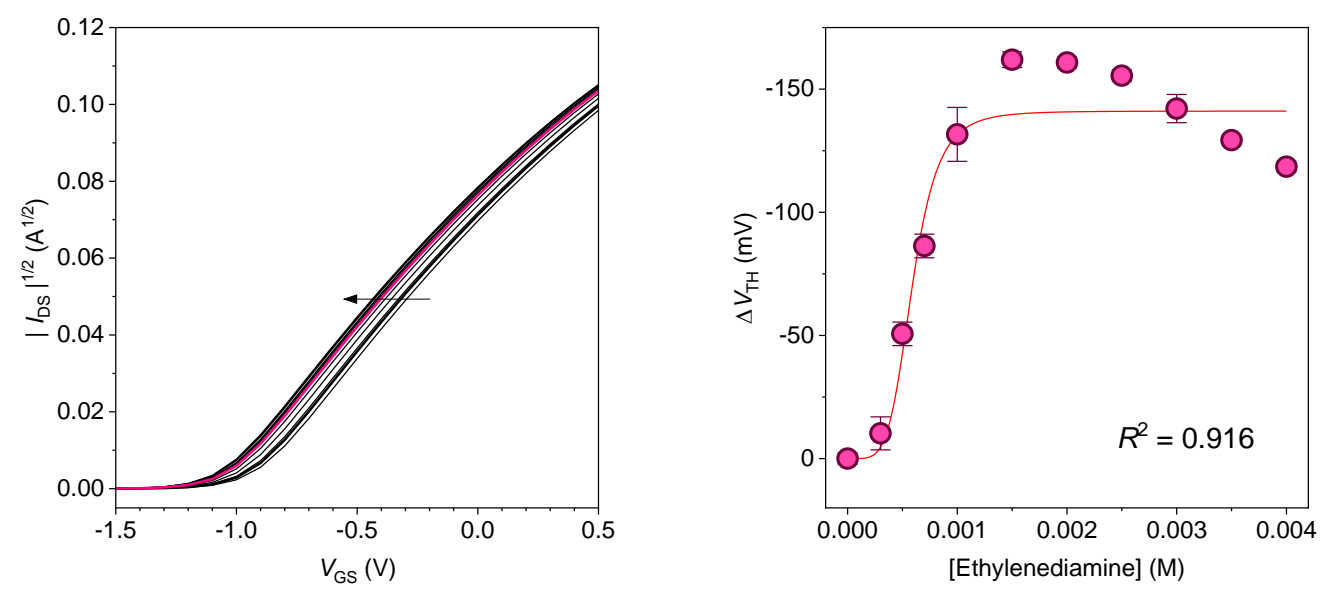

Figure S4. (left) Transfer characteristics of the FET functionalized with the mSAM 50 $([\mathrm{MBA}]=50 \mathrm{~mol} \%)$ upon the addition of ethylenediamine in a HEPES buffer solution $(100 \mathrm{mM})$ with $\mathrm{NaCl}(100 \mathrm{mM})$ at $\mathrm{pH} 7.0$ at $27^{\circ} \mathrm{C}$. [Ethylenediamine] $=0-4000 \mu \mathrm{M}$. (right) Changes in threshold voltage for the FET device by ethylenediamine at various concentrations in a HEPES buffer solution $(100 \mathrm{mM})$ with $\mathrm{NaCl}(100 \mathrm{mM})$ at $\mathrm{pH} 7.0$ at $27^{\circ} \mathrm{C}$. 

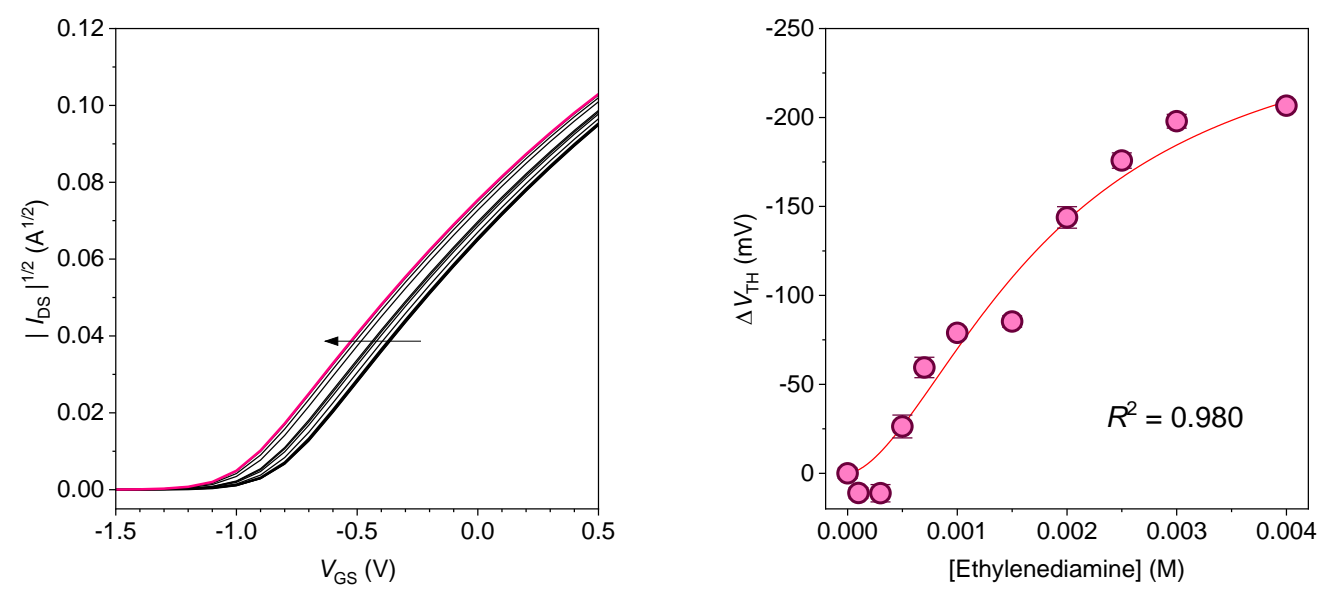

Figure S5. (left) Transfer characteristics of the FET functionalized with the mSAM 75 $([\mathrm{MBA}]=75 \mathrm{~mol} \%)$ upon the addition of ethylenediamine in a HEPES buffer solution $(100 \mathrm{mM})$ with $\mathrm{NaCl}(100 \mathrm{mM})$ at $\mathrm{pH} 7.0$ at $27^{\circ} \mathrm{C}$. [Ethylenediamine] $=0-4000 \mu \mathrm{M}$. (right) Changes in threshold voltage for the FET device by ethylenediamine at various concentrations in a HEPES buffer solution $(100 \mathrm{mM})$ with $\mathrm{NaCl}(100 \mathrm{mM})$ at $\mathrm{pH} 7.0$ at $27^{\circ} \mathrm{C}$. 

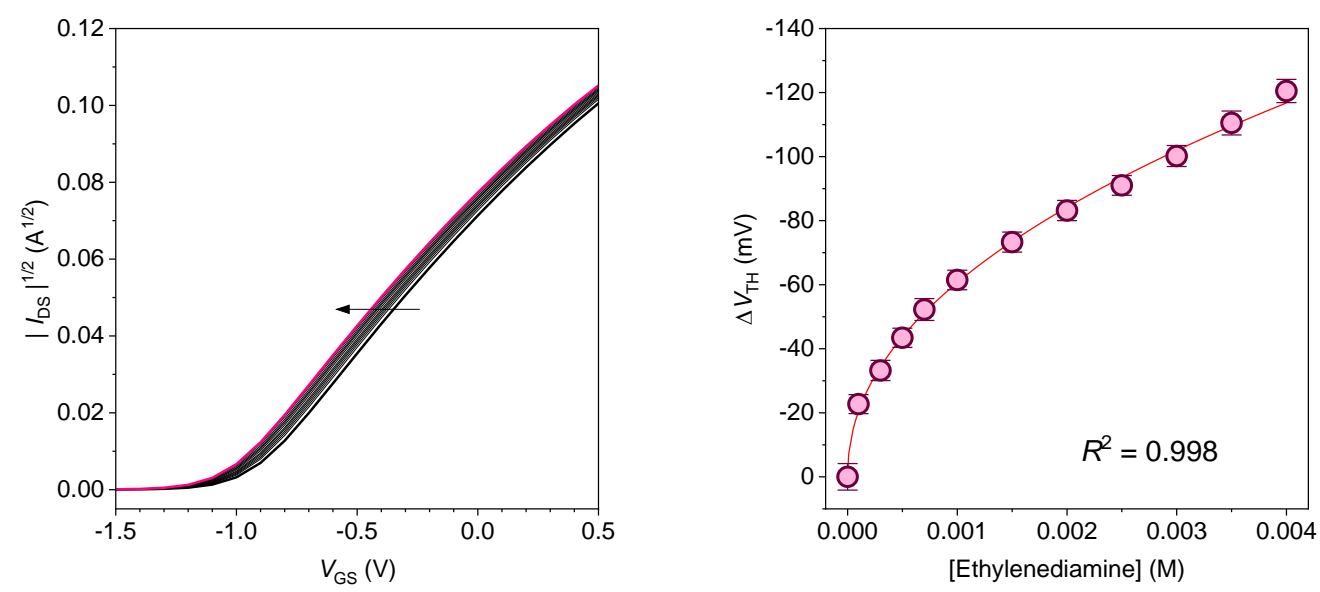

Figure S6. (left) Transfer characteristics of the FET functionalized with the MBA-SAM $([\mathrm{MBA}]=100 \mathrm{~mol} \%)$ upon the addition of ethylenediamine in a HEPES buffer solution $(100 \mathrm{mM})$ with $\mathrm{NaCl}(100 \mathrm{mM})$ at $\mathrm{pH} 7.0$ at $27^{\circ} \mathrm{C}$. [Ethylenediamine] $=0-4000 \mu \mathrm{M}$. (right) Changes in threshold voltage for the FET device by ethylenediamine at various concentrations in a HEPES buffer solution $(100 \mathrm{mM})$ with $\mathrm{NaCl}(100 \mathrm{mM})$ at $\mathrm{pH} 7.0$ at $27^{\circ} \mathrm{C}$. 

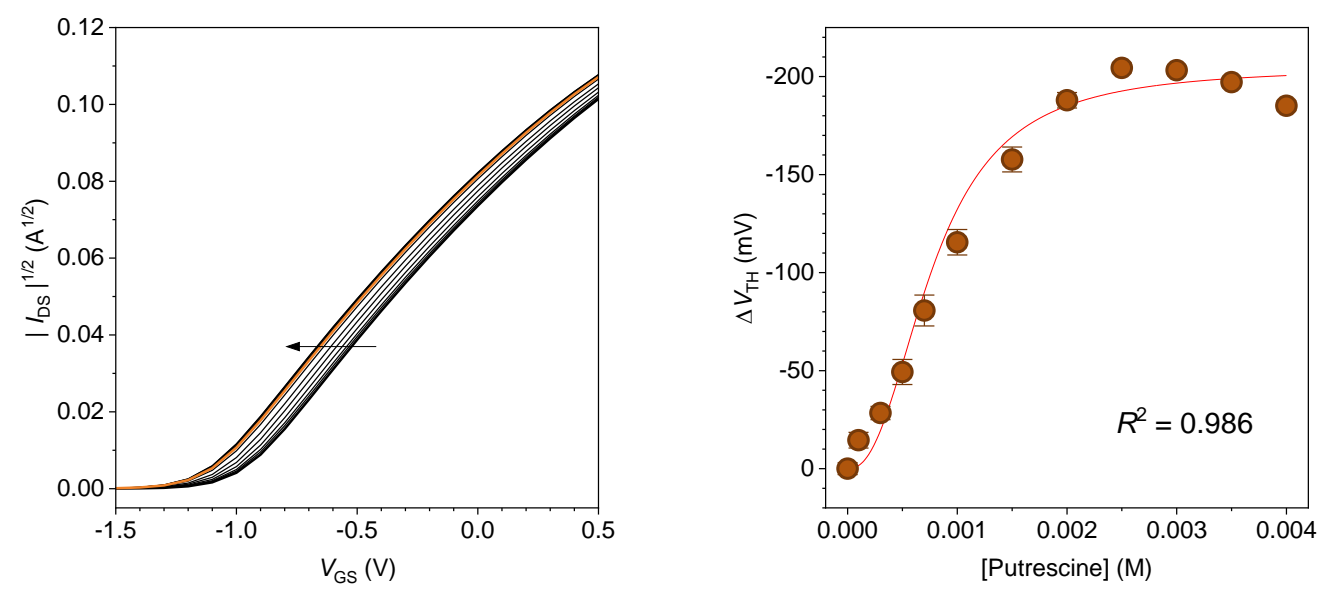

Figure S7. (left) Transfer characteristics of the FET functionalized with the mSAM 10 $([\mathrm{MBA}]=10 \mathrm{~mol} \%)$ upon the addition of putrescine in a HEPES buffer solution $(100$ $\mathrm{mM})$ with $\mathrm{NaCl}(100 \mathrm{mM})$ at $\mathrm{pH} 7.0$ at $27^{\circ} \mathrm{C}$. [Putrescine] $=0-4000 \mu \mathrm{M}$. (right) Changes in threshold voltage for the FET device by putrescine at various concentrations in a HEPES buffer solution $(100 \mathrm{mM})$ with $\mathrm{NaCl}(100 \mathrm{mM})$ at $\mathrm{pH} 7.0$ at $27^{\circ} \mathrm{C}$. 

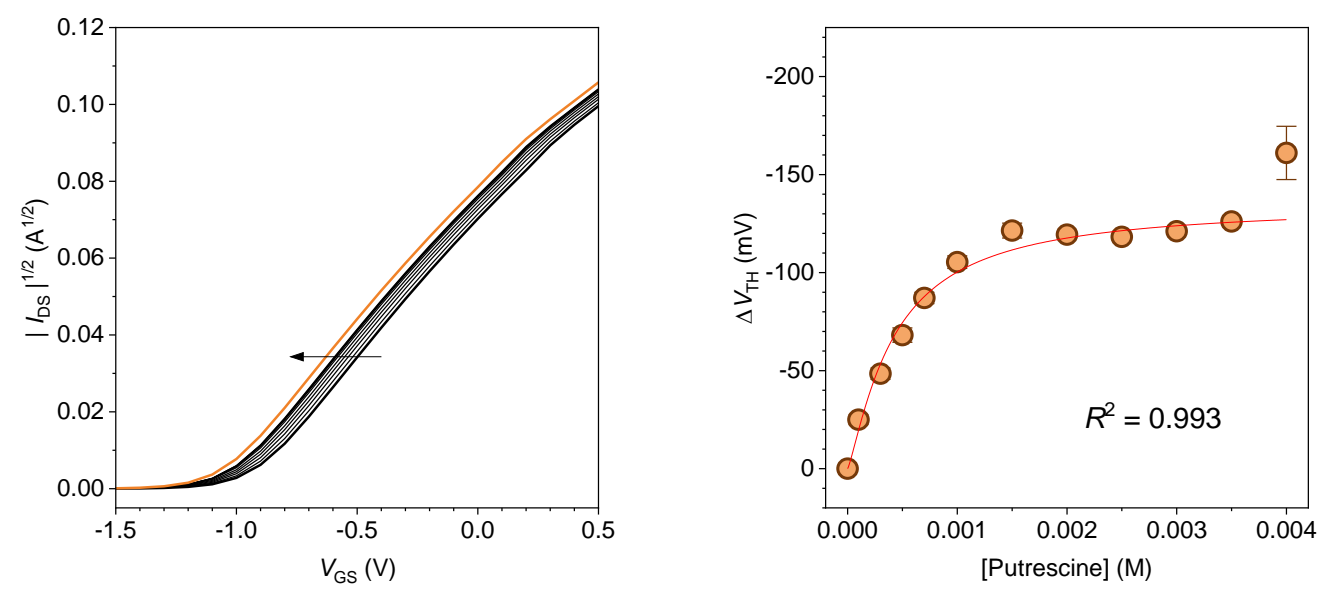

Figure S8. (left) Transfer characteristics of the FET functionalized with the mSAM 50 $([\mathrm{MBA}]=50 \mathrm{~mol} \%)$ upon the addition of putrescine in a HEPES buffer solution $(100$ $\mathrm{mM})$ with $\mathrm{NaCl}(100 \mathrm{mM})$ at $\mathrm{pH} 7.0$ at $27^{\circ} \mathrm{C}$. [Putrescine] $=0-4000 \mu \mathrm{M}$. (right) Changes in threshold voltage for the FET device by putrescine at various concentrations in a HEPES buffer solution $(100 \mathrm{mM})$ with $\mathrm{NaCl}(100 \mathrm{mM})$ at $\mathrm{pH} 7.0$ at $27^{\circ} \mathrm{C}$. 

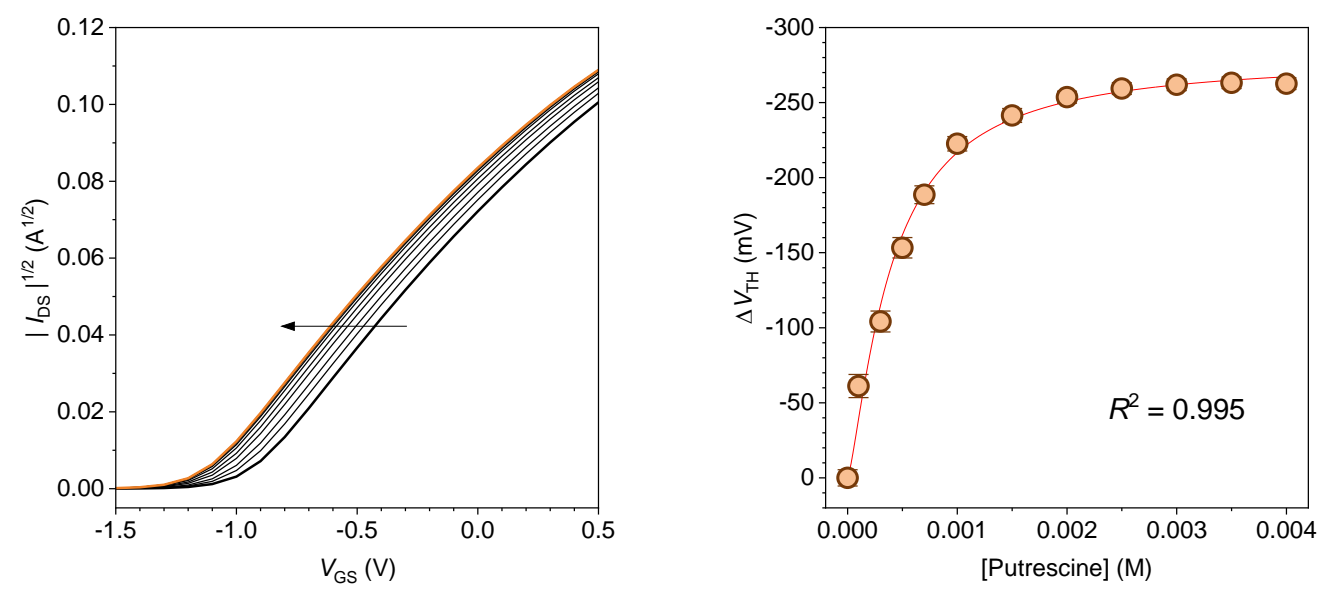

Figure S9. (left) Transfer characteristics of the FET functionalized with the mSAM 75 $([\mathrm{MBA}]=75 \mathrm{~mol} \%)$ upon the addition of putrescine in a HEPES buffer solution $(100$ $\mathrm{mM})$ with $\mathrm{NaCl}(100 \mathrm{mM})$ at $\mathrm{pH} 7.0$ at $27^{\circ} \mathrm{C}$. [Putrescine] $=0-4000 \mu \mathrm{M}$. (right) Changes in threshold voltage for the FET device by putrescine at various concentrations in a HEPES buffer solution $(100 \mathrm{mM})$ with $\mathrm{NaCl}(100 \mathrm{mM})$ at $\mathrm{pH} 7.0$ at $27^{\circ} \mathrm{C}$. 

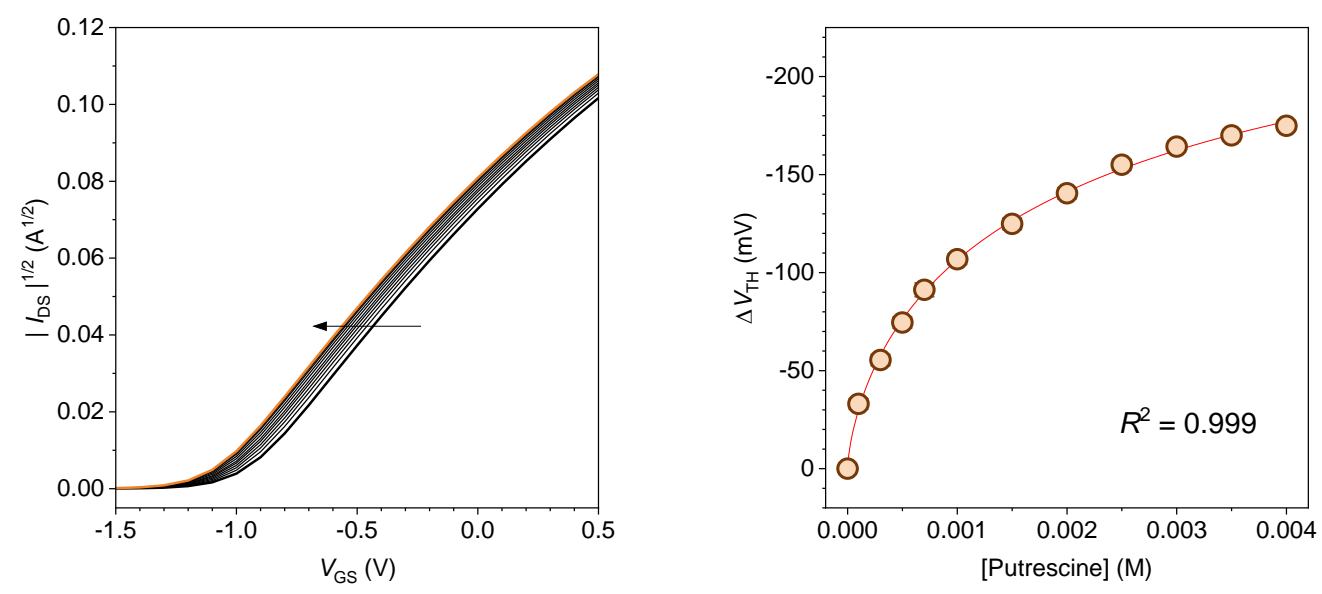

Figure S10. (left) Transfer characteristics of the FET functionalized with the MBA-SAM $([\mathrm{MBA}]=100 \mathrm{~mol} \%)$ upon the addition of putrescine in a HEPES buffer solution $(100$ $\mathrm{mM})$ with $\mathrm{NaCl}(100 \mathrm{mM})$ at $\mathrm{pH} 7.0$ at $27^{\circ} \mathrm{C}$. [Putrescine] $=0-4000 \mu \mathrm{M}$. (right) Changes in threshold voltage for the FET device by putrescine at various concentrations in a HEPES buffer solution $(100 \mathrm{mM})$ with $\mathrm{NaCl}(100 \mathrm{mM})$ at $\mathrm{pH} 7.0$ at $27^{\circ} \mathrm{C}$. 

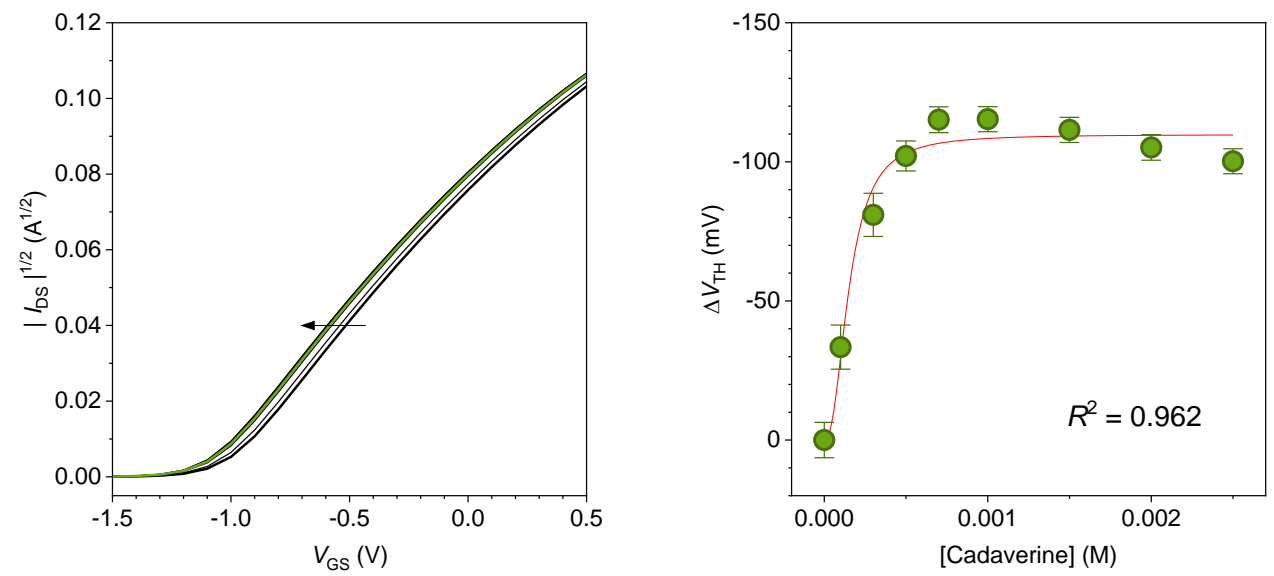

Figure S11. (left) Transfer characteristics of the FET functionalized with the mSAM 10 $([\mathrm{MBA}]=10 \mathrm{~mol} \%)$ upon the addition of cadaverine in a HEPES buffer solution $(100$ $\mathrm{mM})$ with $\mathrm{NaCl}(100 \mathrm{mM})$ at $\mathrm{pH} 7.0$ at $27^{\circ} \mathrm{C}$. [Cadaverine] $=0-2500 \mu \mathrm{M}$. (right) Changes in threshold voltage for the FET device by cadaverine at various concentrations in a HEPES buffer solution $(100 \mathrm{mM})$ with $\mathrm{NaCl}(100 \mathrm{mM})$ at $\mathrm{pH} 7.0$ at $27^{\circ} \mathrm{C}$. 

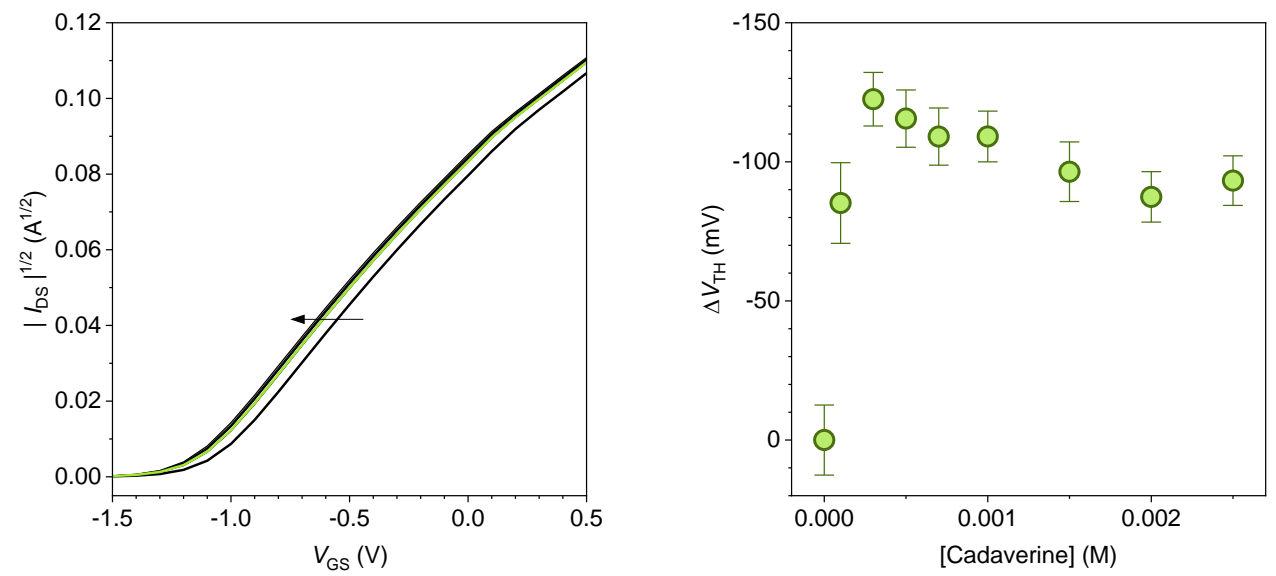

Figure S12. (left) Transfer characteristics of the FET functionalized with the mSAM 50 $([\mathrm{MBA}]=50 \mathrm{~mol} \%)$ upon the addition of cadaverine in a HEPES buffer solution $(100$ $\mathrm{mM})$ with $\mathrm{NaCl}(100 \mathrm{mM})$ at $\mathrm{pH} 7.0$ at $27^{\circ} \mathrm{C}$. [Cadaverine] $=0-2500 \mu \mathrm{M}$. (right) Changes in threshold voltage for the FET device by cadaverine at various concentrations in a HEPES buffer solution $(100 \mathrm{mM})$ with $\mathrm{NaCl}(100 \mathrm{mM})$ at $\mathrm{pH} 7.0$ at $27^{\circ} \mathrm{C}$. 

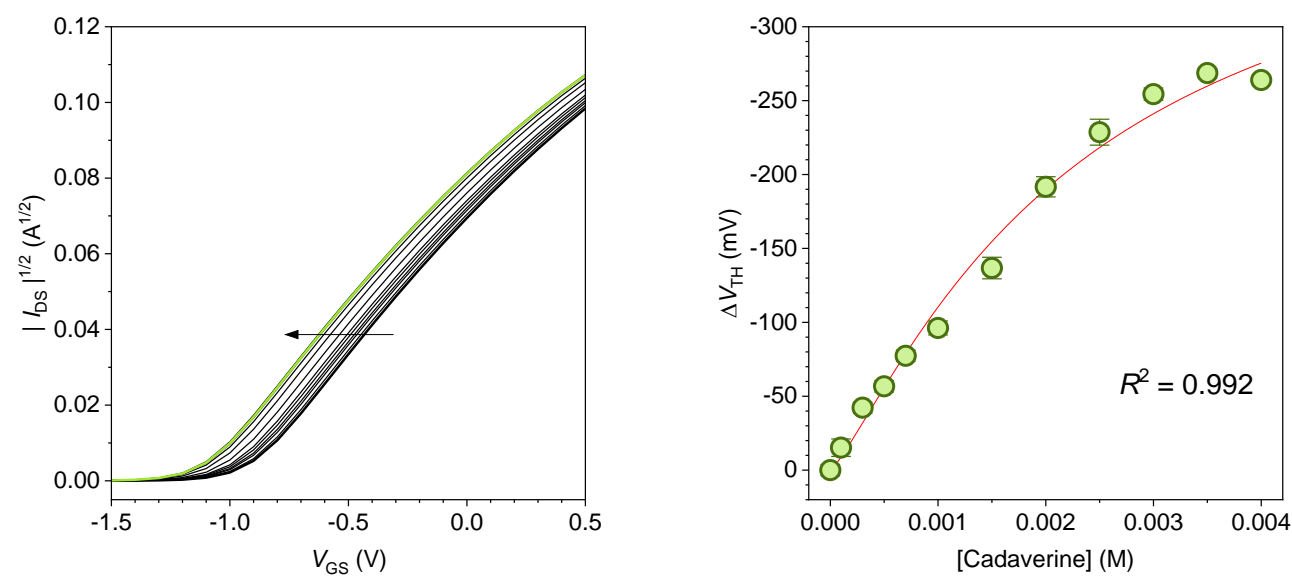

Figure S13. (left) Transfer characteristics of the FET functionalized with the mSAM 75 $([\mathrm{MBA}]=75 \mathrm{~mol} \%)$ upon the addition of cadaverine in a HEPES buffer solution $(100$ $\mathrm{mM})$ with $\mathrm{NaCl}(100 \mathrm{mM})$ at $\mathrm{pH} 7.0$ at $27^{\circ} \mathrm{C}$. [Cadaverine] $=0-4000 \mu \mathrm{M}$. (right) Changes in threshold voltage for the FET device by cadaverine at various concentrations in a HEPES buffer solution $(100 \mathrm{mM})$ with $\mathrm{NaCl}(100 \mathrm{mM})$ at $\mathrm{pH} 7.0$ at $27^{\circ} \mathrm{C}$. 

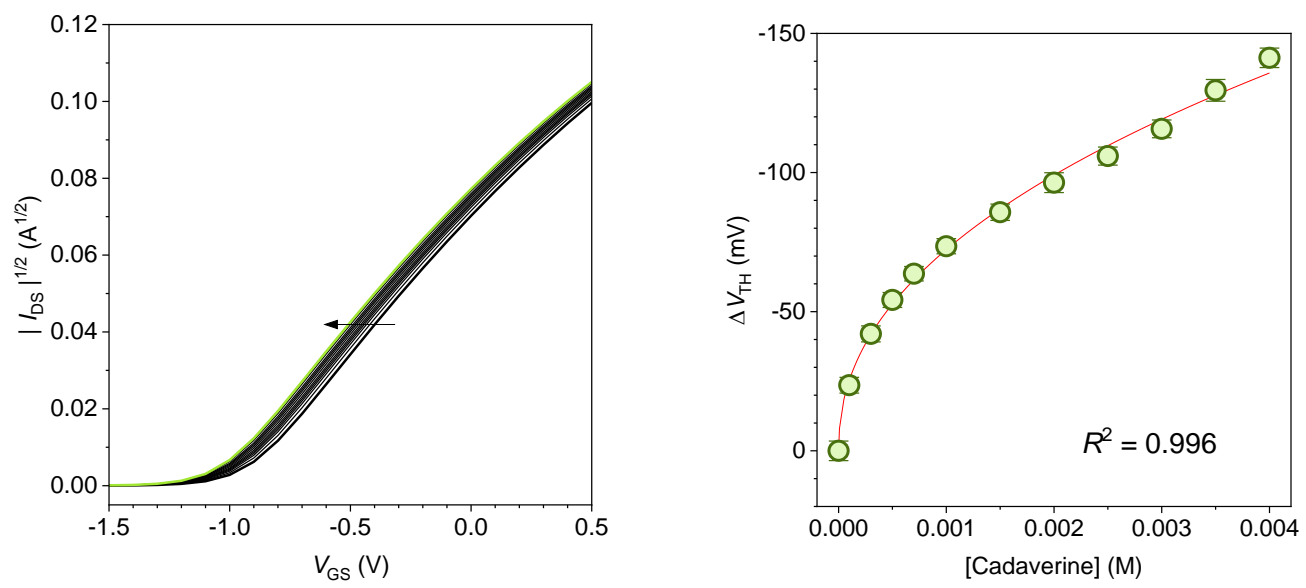

Figure S14. (left) Transfer characteristics of the FET functionalized with the MBA-SAM $([\mathrm{MBA}]=100 \mathrm{~mol} \%)$ upon the addition of cadaverine in a HEPES buffer solution $(100$ $\mathrm{mM})$ with $\mathrm{NaCl}(100 \mathrm{mM})$ at $\mathrm{pH} 7.0$ at $27^{\circ} \mathrm{C}$. [Cadaverine] $=0-4000 \mu \mathrm{M}$. (right) Changes in threshold voltage for the FET device by cadaverine at various concentrations in a HEPES buffer solution $(100 \mathrm{mM})$ with $\mathrm{NaCl}(100 \mathrm{mM})$ at $\mathrm{pH} 7.0$ at $27^{\circ} \mathrm{C}$. 

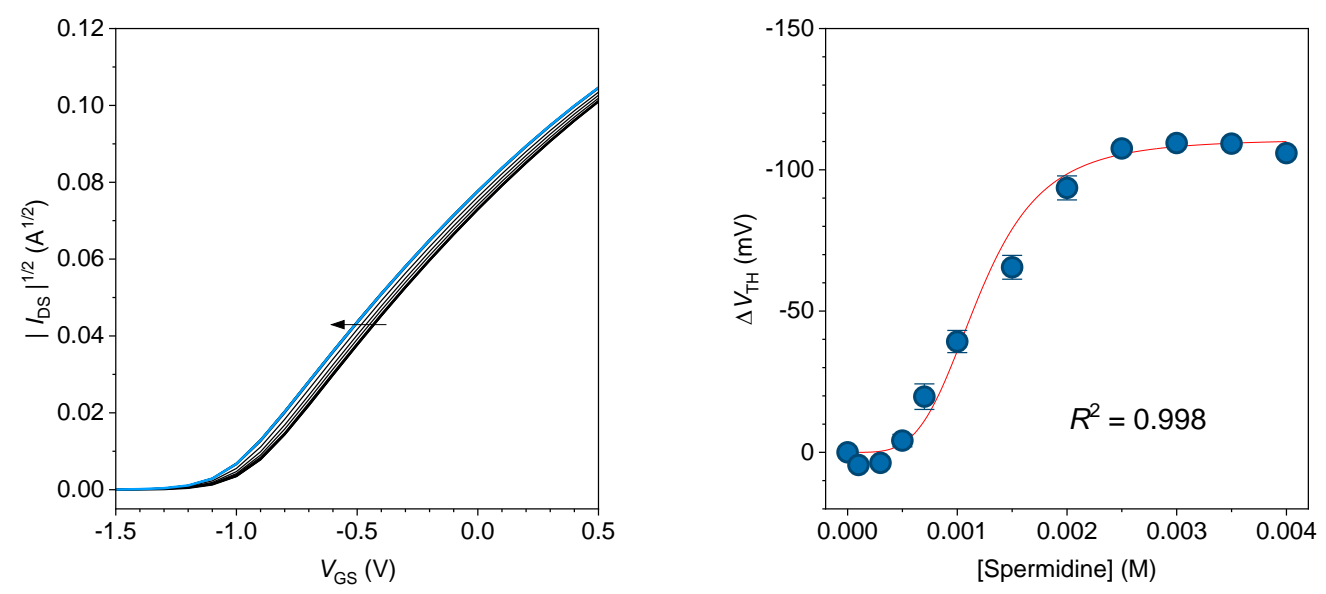

Figure S15. (left) Transfer characteristics of the FET functionalized with the mSAM 10 $([\mathrm{MBA}]=10 \mathrm{~mol} \%)$ upon the addition of spermidine in a HEPES buffer solution $(100$ $\mathrm{mM}$ ) with $\mathrm{NaCl}(100 \mathrm{mM})$ at $\mathrm{pH} 7.0$ at $27^{\circ} \mathrm{C}$. [Spermidine] $=0-4000 \mu \mathrm{M}$. (right) Changes in threshold voltage for the FET device by spermidine at various concentrations in a HEPES buffer solution $(100 \mathrm{mM})$ with $\mathrm{NaCl}(100 \mathrm{mM})$ at $\mathrm{pH} 7.0$ at $27^{\circ} \mathrm{C}$. 

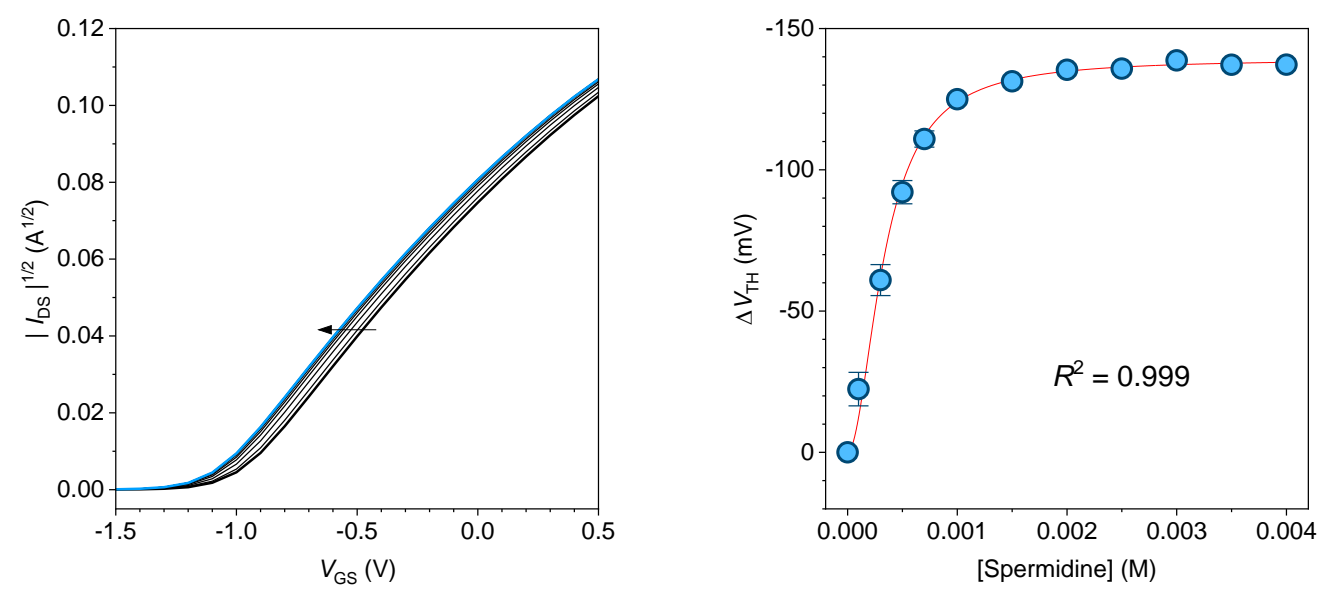

Figure S16. (left) Transfer characteristics of the FET functionalized with the mSAM 50 $([\mathrm{MBA}]=50 \mathrm{~mol} \%)$ upon the addition of spermidine in a HEPES buffer solution $(100$ $\mathrm{mM})$ with $\mathrm{NaCl}(100 \mathrm{mM})$ at $\mathrm{pH} 7.0$ at $27^{\circ} \mathrm{C}$. [Spermidine] $=0-4000 \mu \mathrm{M}$. (right) Changes in threshold voltage for the FET device by spermidine at various concentrations in a HEPES buffer solution $(100 \mathrm{mM})$ with $\mathrm{NaCl}(100 \mathrm{mM})$ at $\mathrm{pH} 7.0$ at $27^{\circ} \mathrm{C}$. 

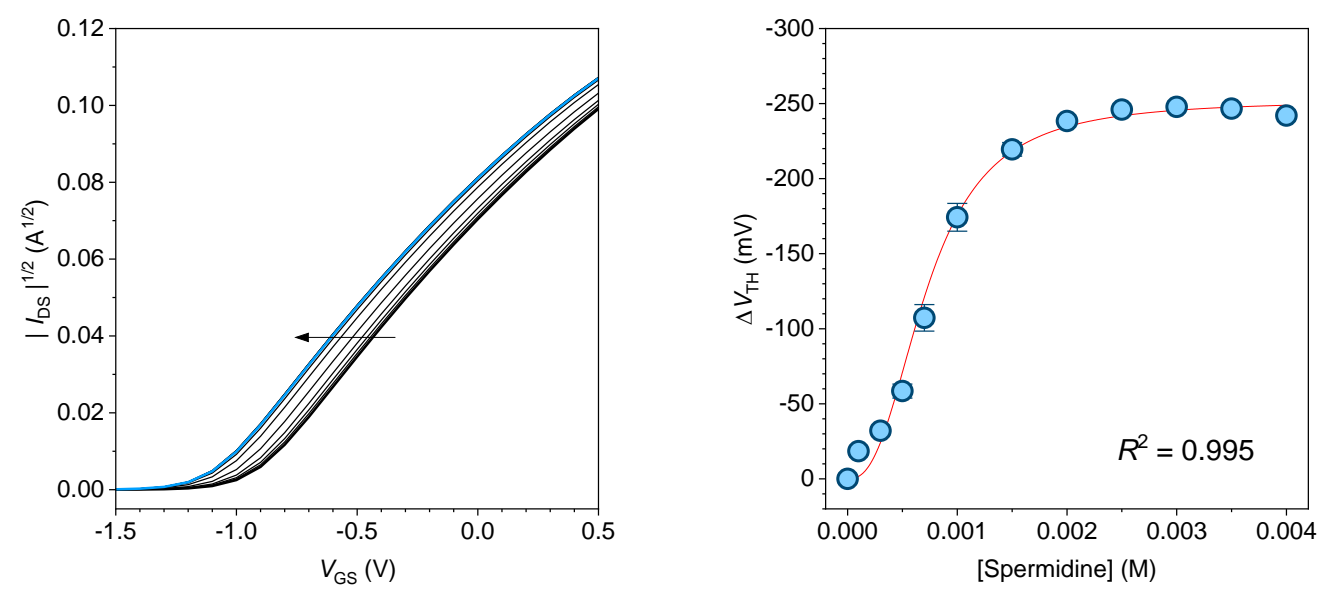

Figure S17. (left) Transfer characteristics of the FET functionalized with the mSAM 75 $([\mathrm{MBA}]=75 \mathrm{~mol} \%)$ upon the addition of spermidine in a HEPES buffer solution $(100$ $\mathrm{mM})$ with $\mathrm{NaCl}(100 \mathrm{mM})$ at $\mathrm{pH} 7.0$ at $27^{\circ} \mathrm{C}$. [Spermidine] $=0-4000 \mu \mathrm{M}$. (right) Changes in threshold voltage for the FET device by spermidine at various concentrations in a HEPES buffer solution $(100 \mathrm{mM})$ with $\mathrm{NaCl}(100 \mathrm{mM})$ at $\mathrm{pH} 7.0$ at $27^{\circ} \mathrm{C}$. 

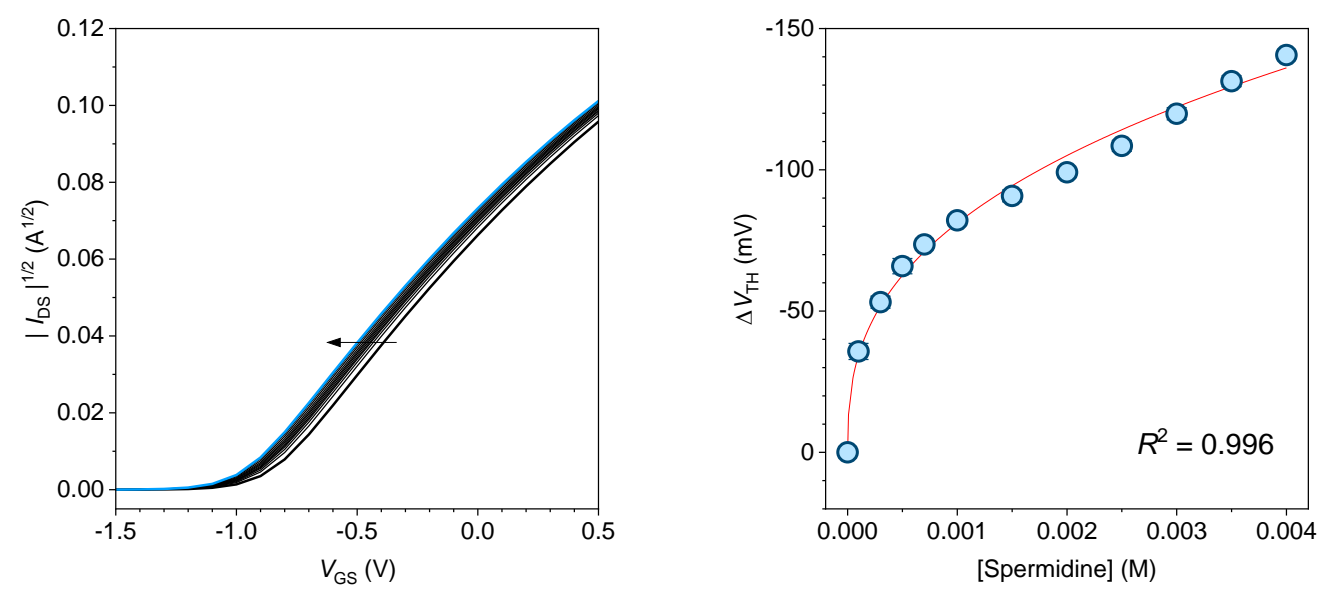

Figure S18. (left) Transfer characteristics of the FET functionalized with the MBA-SAM $([\mathrm{MBA}]=100 \mathrm{~mol} \%)$ upon the addition of spermidine in a HEPES buffer solution $(100$ $\mathrm{mM})$ with $\mathrm{NaCl}(100 \mathrm{mM})$ at $\mathrm{pH} 7.0$ at $27^{\circ} \mathrm{C}$. [Spermidine] $=0-4000 \mu \mathrm{M}$. (right) Changes in threshold voltage for the FET device by spermidine at various concentrations in a HEPES buffer solution $(100 \mathrm{mM})$ with $\mathrm{NaCl}(100 \mathrm{mM})$ at $\mathrm{pH} 7.0$ at $27^{\circ} \mathrm{C}$. 

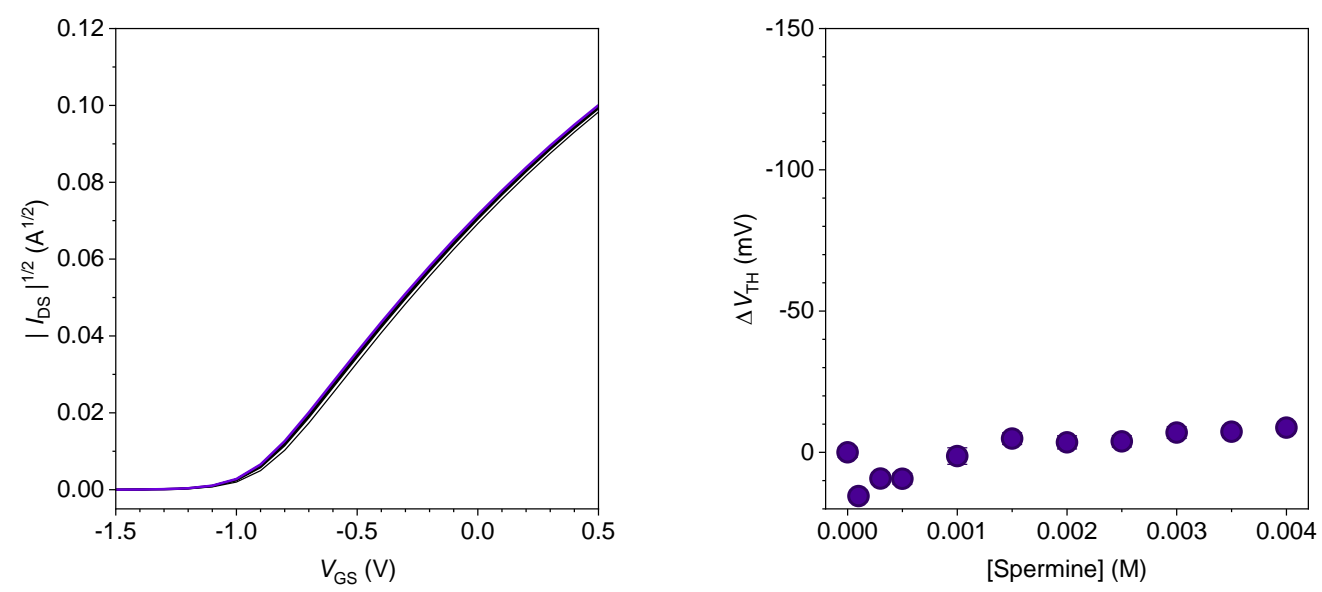

Figure S19. (left) Transfer characteristics of the FET functionalized with the mSAM 10 $([\mathrm{MBA}]=10 \mathrm{~mol} \%)$ upon the addition of spermine in a HEPES buffer solution $(100 \mathrm{mM})$ with $\mathrm{NaCl}(100 \mathrm{mM})$ at $\mathrm{pH} 7.0$ at $27^{\circ} \mathrm{C}$. [Spermine] $=0-4000 \mu \mathrm{M}$. (right) Changes in threshold voltage for the FET device by spermine at various concentrations in a HEPES buffer solution $(100 \mathrm{mM})$ with $\mathrm{NaCl}(100 \mathrm{mM})$ at $\mathrm{pH} 7.0$ at $27^{\circ} \mathrm{C}$. 

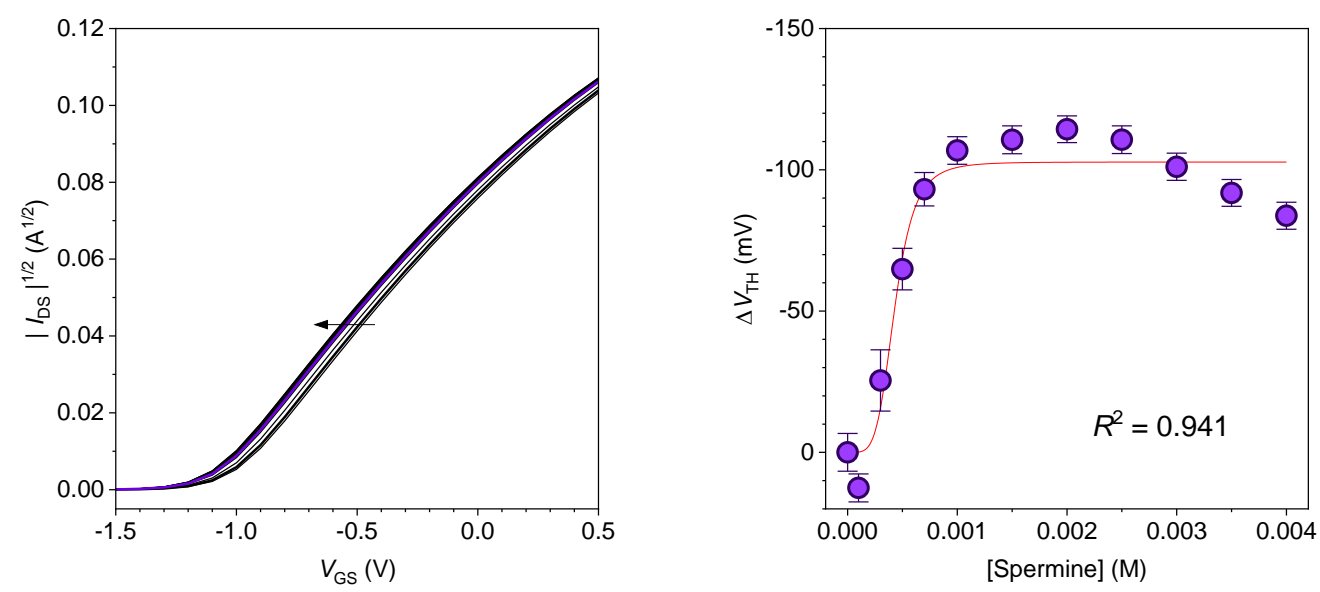

Figure S20. (left) Transfer characteristics of the FET functionalized with the mSAM 50 $([\mathrm{MBA}]=50 \mathrm{~mol} \%)$ upon the addition of spermine in a HEPES buffer solution $(100 \mathrm{mM})$ with $\mathrm{NaCl}(100 \mathrm{mM})$ at $\mathrm{pH} 7.0$ at $27^{\circ} \mathrm{C}$. [Spermine] $=0-4000 \mu \mathrm{M}$. (right) Changes in threshold voltage for the FET device by spermine at various concentrations in a HEPES buffer solution $(100 \mathrm{mM})$ with $\mathrm{NaCl}(100 \mathrm{mM})$ at $\mathrm{pH} 7.0$ at $27^{\circ} \mathrm{C}$. 

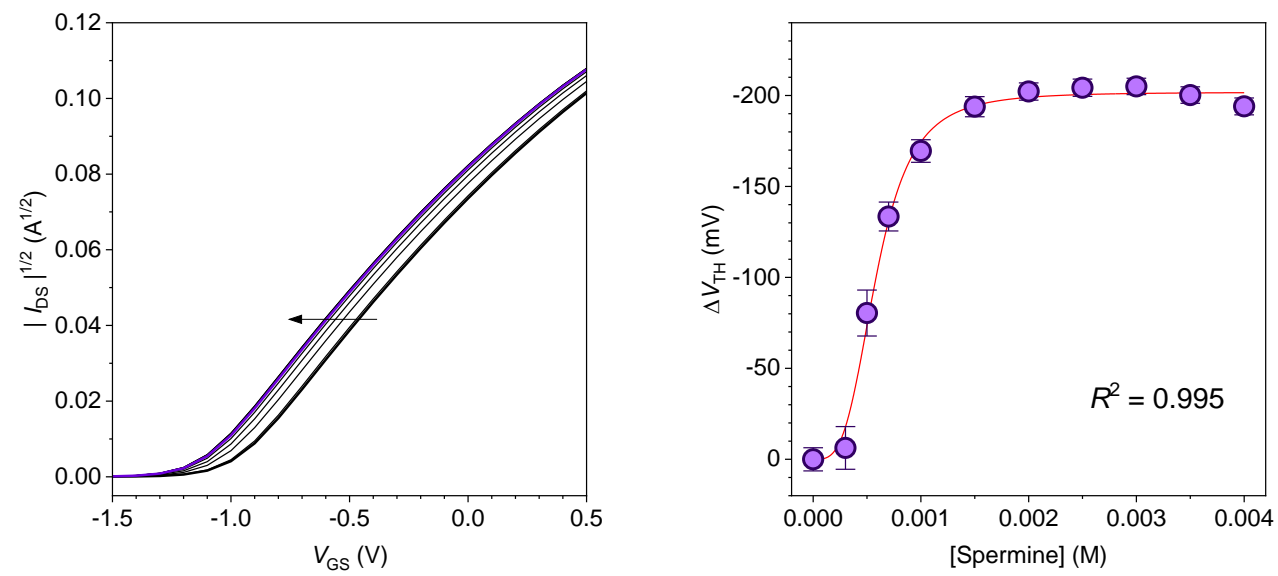

Figure S21. (left) Transfer characteristics of the FET functionalized with the mSAM 75 $([\mathrm{MBA}]=75 \mathrm{~mol} \%)$ upon the addition of spermine in a HEPES buffer solution $(100 \mathrm{mM})$ with $\mathrm{NaCl}(100 \mathrm{mM})$ at $\mathrm{pH} 7.0$ at $27^{\circ} \mathrm{C}$. [Spermine] $=0-4000 \mu \mathrm{M}$. (right) Changes in threshold voltage for the FET device by spermine at various concentrations in a HEPES buffer solution $(100 \mathrm{mM})$ with $\mathrm{NaCl}(100 \mathrm{mM})$ at $\mathrm{pH} 7.0$ at $27^{\circ} \mathrm{C}$. 

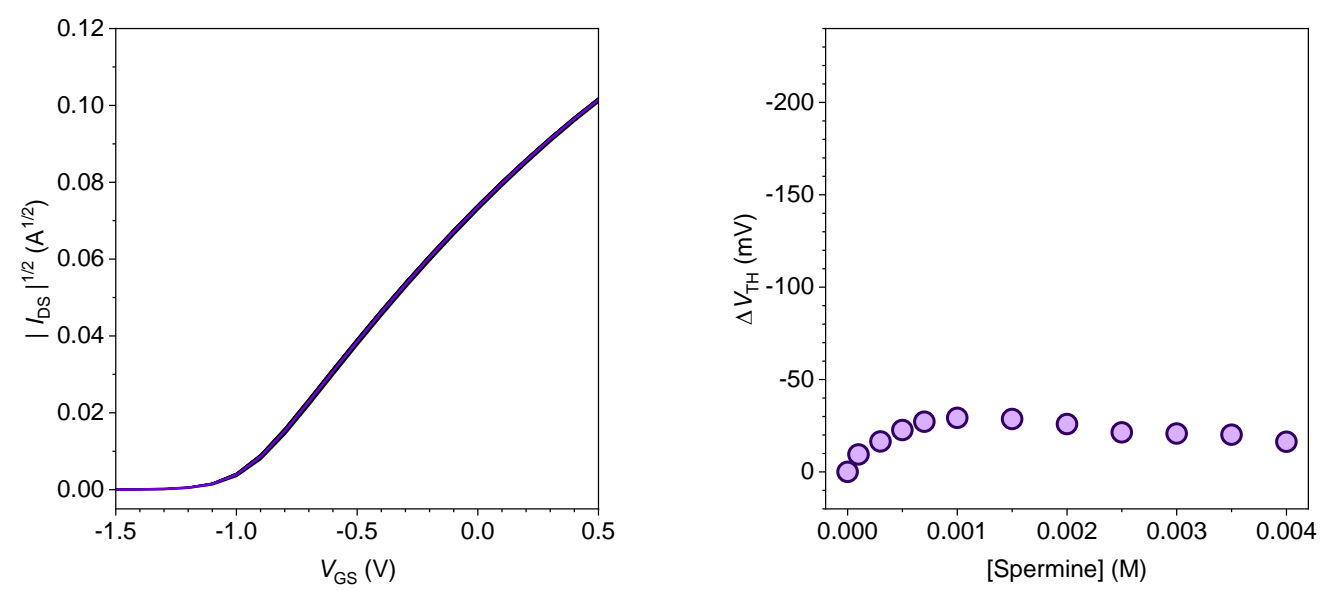

Figure S22. (left) Transfer characteristics of the FET functionalized with the MBA-SAM $([\mathrm{MBA}]=100 \mathrm{~mol} \%)$ upon the addition of spermine in a HEPES buffer solution $(100$ $\mathrm{mM})$ with $\mathrm{NaCl}(100 \mathrm{mM})$ at $\mathrm{pH} 7.0$ at $27^{\circ} \mathrm{C}$. [Spermine] $=0-4000 \mu \mathrm{M}$. (right) Changes in threshold voltage for the FET device by spermine at various concentrations in a HEPES buffer solution $(100 \mathrm{mM})$ with $\mathrm{NaCl}(100 \mathrm{mM})$ at $\mathrm{pH} 7.0$ at $27^{\circ} \mathrm{C}$. 


\section{The $\mathrm{p} K_{\mathrm{a}}$ values of the reagents.}

Table S4. The $\mathrm{p} K_{\mathrm{a}}$ values of benzoic acid, MBA, and biogenic amines.

\begin{tabular}{lll}
\hline Compound & $\mathbf{p} \boldsymbol{K}_{\mathbf{a}}$ & Reference \\
\hline $\begin{array}{l}\text { Benzoic acid (unbound } \\
\text { form) }\end{array}$ & 4.19 & Langmuir 1996, 12, 726. ${ }^{4}$ \\
\hline $\begin{array}{l}\text { 4-Mercaptobenzoic acid } \\
\text { (MBA, SAM form) }\end{array}$ & 4.79 & Langmuir 2003, 19, 7003. ${ }^{5}$ \\
\hline MBA-SAM (this study) & 5.5 & Figure S28 \\
\hline Ethylenediamine & $9.93-10.58$ & J. Chem. Eng. Data 2005, 50, 1917. ${ }^{6}$ \\
\hline Putrescine & 10.68 & New J. Chem. 2018, 42, 1202. \\
\hline Cadaverine & 9.99 & J. Chem. Soc., Perkin Trans. 2 1985, 1865. \\
\hline Spermidine & 10.85 & J. Chem. Soc., Faraday Trans. 1998, 94, \\
\hline Spermine & & 1091. ${ }^{7}$ \\
\hline
\end{tabular}


8. Cycle measurements.

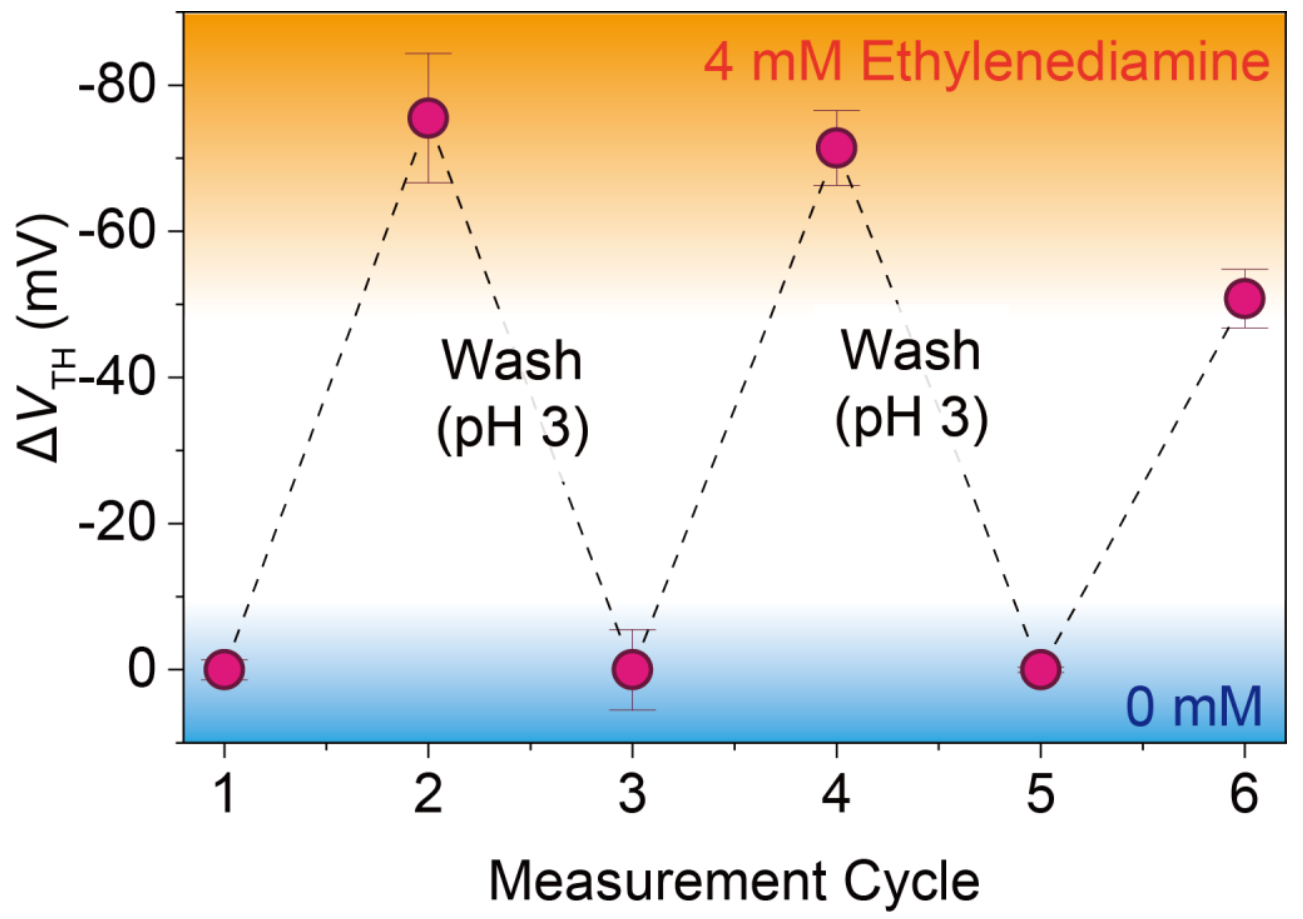

Figure S23. Changes in the threshold voltage of the FET device upon alternating treatment by acidic aqueous solution $(100 \mathrm{mM} \mathrm{NaCl}, \mathrm{pH} 3.0)$ and $4 \mathrm{mM}$ solution of ethylenediamine in a buffer solution (100 mM HEPES, $100 \mathrm{mM} \mathrm{NaCl}, \mathrm{pH} 7.0)$. The FET device with the extended-gate modified by the mSAM 10 was utilized as the sensor. 


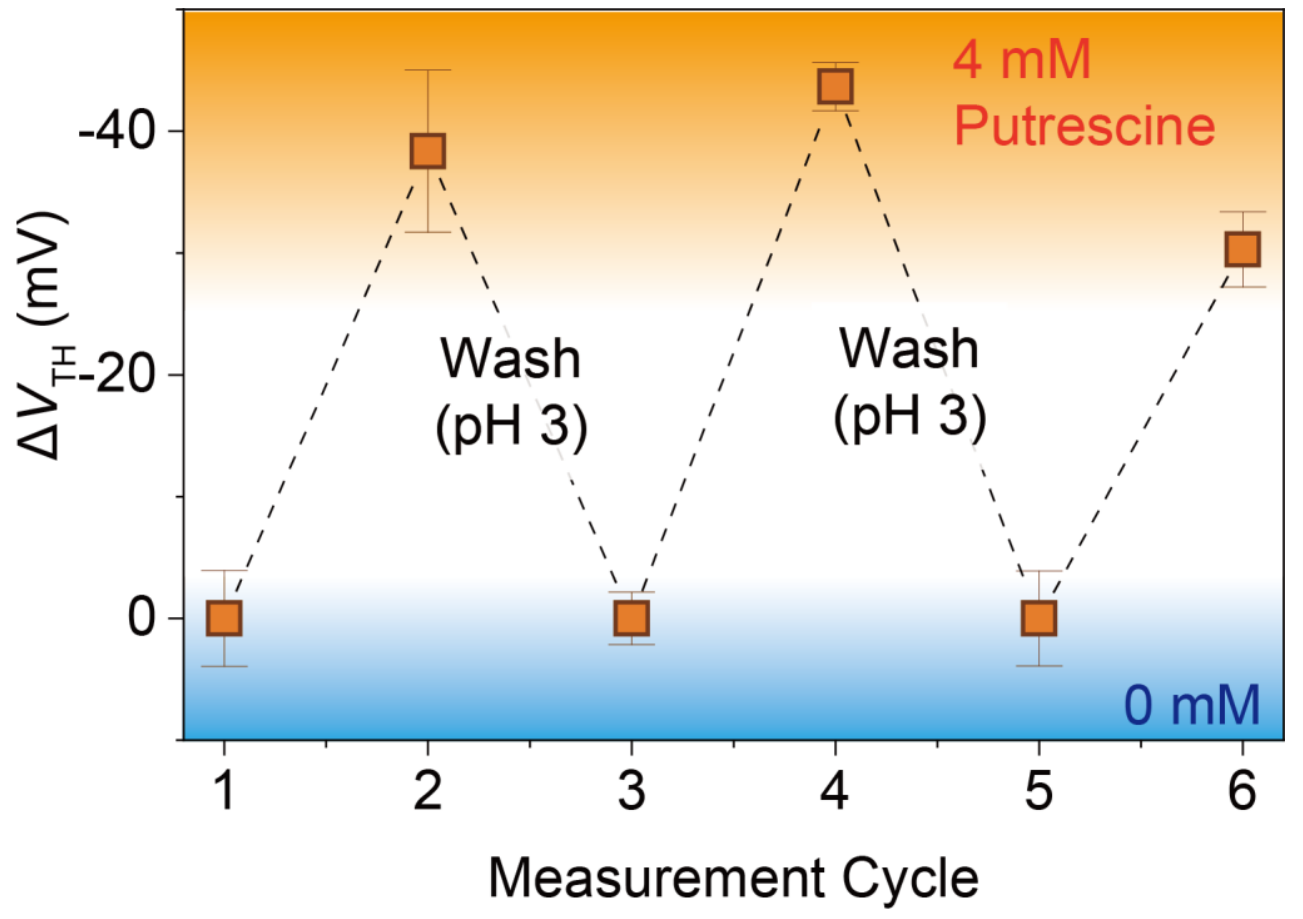

Figure S24. Changes in the threshold voltage of the FET device upon alternating treatment by acidic aqueous solution $(100 \mathrm{mM} \mathrm{NaCl}, \mathrm{pH} 3.0)$ and $4 \mathrm{mM}$ solution of putrescine in a buffer solution (100 mM HEPES, $100 \mathrm{mM} \mathrm{NaCl}, \mathrm{pH}$ 7.0). The FET device with the extended-gate modified by the mSAM 10 was utilized as the sensor. 


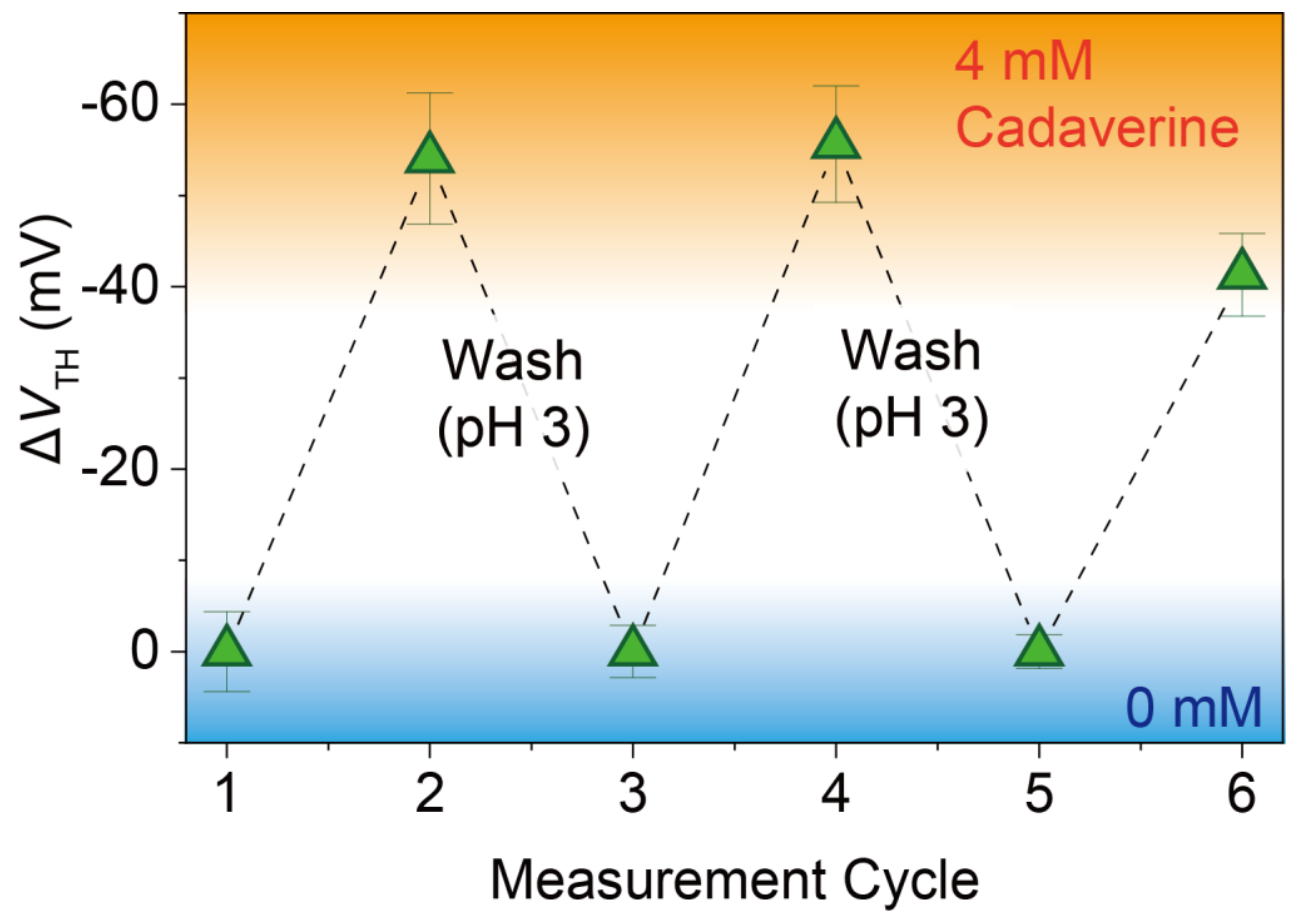

Figure S25. Changes in the threshold voltage of the FET device upon alternating treatment by acidic aqueous solution $(100 \mathrm{mM} \mathrm{NaCl}, \mathrm{pH} 3.0)$ and $4 \mathrm{mM}$ solution of cadaverine in a buffer solution (100 mM HEPES, $100 \mathrm{mM} \mathrm{NaCl}, \mathrm{pH} 7.0)$. The FET device with the extended-gate modified by the mSAM 10 was utilized as the sensor. 


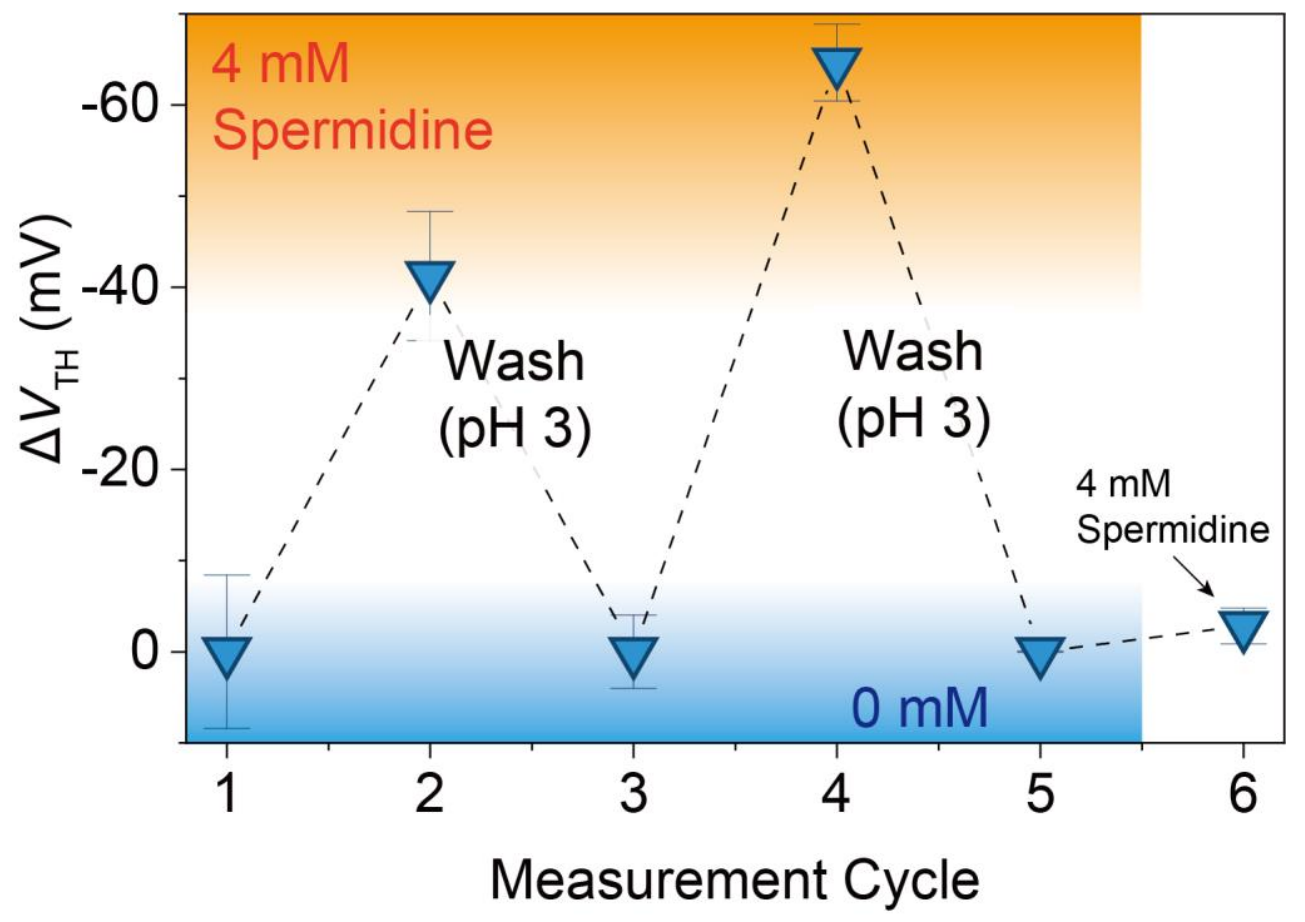

Figure S26. Changes in the threshold voltage of the FET device upon alternating treatment by acidic aqueous solution $(100 \mathrm{mM} \mathrm{NaCl}, \mathrm{pH} 3.0)$ and $4 \mathrm{mM}$ solution of spermidine in a buffer solution (100 mM HEPES, $100 \mathrm{mM} \mathrm{NaCl}, \mathrm{pH} 7.0)$. The FET device with the extended-gate modified by the mSAM 10 was utilized as the sensor. 


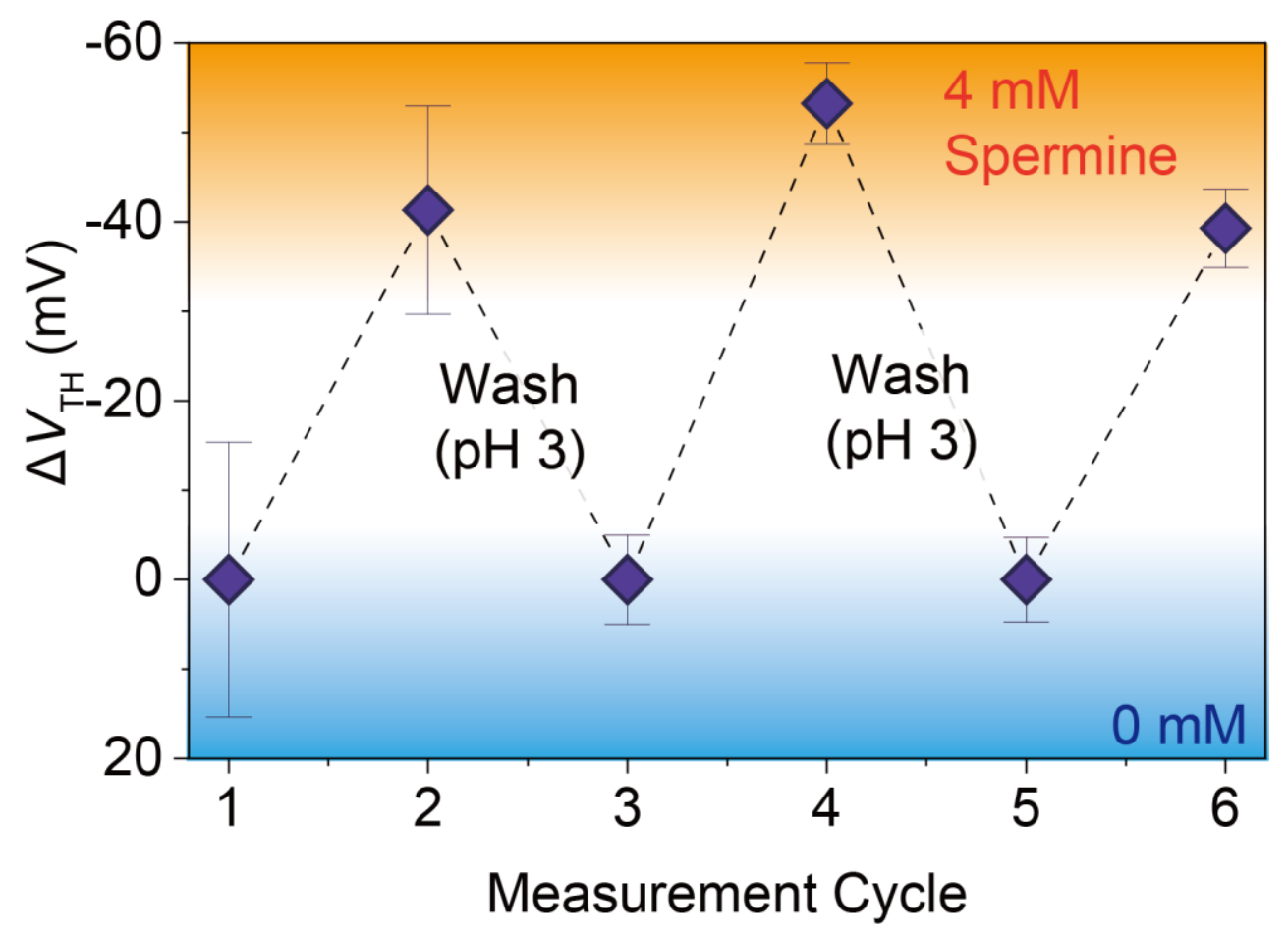

Figure S27. Changes in the threshold voltage of the FET device upon alternating treatment by acidic aqueous solution $(100 \mathrm{mM} \mathrm{NaCl}, \mathrm{pH} 3.0)$ and $4 \mathrm{mM}$ solution of spermine in a buffer solution (100 mM HEPES, $100 \mathrm{mM} \mathrm{NaCl}, \mathrm{pH}$ 7.0). The FET device with the extended-gate modified by the mSAM 10 was utilized as the sensor. 


\section{9. $\mathbf{p H}$ titration. ${ }^{10}$}

$\mathrm{pH}$-dependent transfer characteristics of the FET functionalized with the MBA-SAM were obtained. The $\mathrm{p} K_{\mathrm{a}}$ value could be calculated from the threshold voltage (Figure S28) using the following equation:

$$
V_{\mathrm{TH}}=\frac{\left(V_{\mathrm{TH}(0)}+V_{\mathrm{TH}(\max )} K_{\mathrm{a}}\left[\mathrm{H}^{+}\right]\right)}{\left(1+K_{\mathrm{a}}\left[\mathrm{H}^{+}\right]\right)}
$$

when $V_{\mathrm{TH}}$ is the threshold voltage for a particular concentration of proton; $V_{\mathrm{TH}(0)}$ is initial threshold voltage of the titration experiment; $V_{\mathrm{TH}(\max )}$ is the maximum threshold voltage in the titration experiment; $K_{\mathrm{a}}$ is the acid dissociation constant; $\left[\mathrm{H}^{+}\right]$is the concentration of proton. The $\mathrm{p} K_{\mathrm{a}}$ profile can be analyzed using nonlinear curve fitting based on the Levenberg-Marquardt algorithm in OriginPro 2018 (Originlab Corp.). The estimated $\mathrm{p} K_{\mathrm{a}}$ value of the MBA-SAM was 5.5 (Table S4).

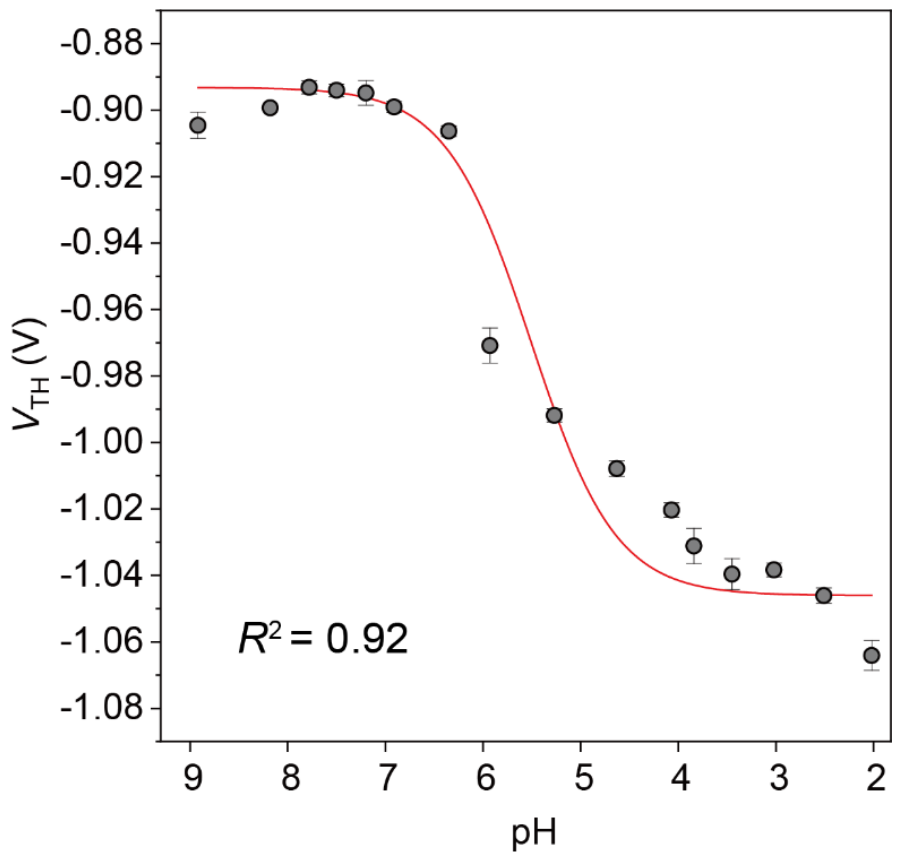

Figure S28. pH-dependency of the threshold voltage of the FET modified with the MBASAM with water containing $\mathrm{NaCl}(100 \mathrm{mM})$ at $27^{\circ} \mathrm{C}$. 


\section{Estimation of the limit of detection. ${ }^{11}$}

For the determination of the limit of detection (LOD) toward the analyte, the intersection of the minimum signal $(=Y)$ and the regression line obtained from the value of $\Delta V_{\mathrm{TH}}$ in the dynamic range of the titration curve allowed us to estimate the value of the LOD. The value of $Y$ is estimated by the following equation:

$$
Y=V_{\mathrm{TH}(\mathrm{avg})}-3 \sigma
$$

$V_{\mathrm{TH}(\text { avg) }}$ and $\sigma$ are the average value and the standard deviation of threshold voltage in the absence of the analyte, respectively. 


\section{References.}

1 Minamiki, T.; Hashima, Y.; Sasaki, Y.; Minami, T. An Electrolyte-Gated Polythiophene Transistor for the Detection of Biogenic Amines in Water. Chem. Commun. 2018, 54, 6907-6910.

${ }^{2}$ Lencer, W. I.; Chu, S. H.; Walker, W. A. Differential Binding Kinetics of Cholera Toxin to Intestinal Microvillus Membrane During Development. Infect. Immunol. 1987, 55, 3126-3130.

3 Shi, J.; Yang, T.; Kataoka, S.; Zhang, Y.; Diaz, A. J.; Cremer, P. S. GM 1 Clustering Inhibits Cholera Toxin Binding in Supported Phospholipid Membranes. J. Am. Chem. Soc. 2007, 129, 5954-5961.

4 Yang, H. C.; Dermody, D. L.; Xu, C.; Ricco, A. J.; Crooks, R. M. Molecular Interactions between Organized, Surface-Confined Monolayers and Vapor-Phase Probe Molecules. 8. Reactions between Acid-Terminated Self-Assembled Monolayers and Vapor-Phase Bases. Langmuir 1996, 12, 726-735.

5 Hiramatsu, H.; Osterloh, F. E. pH-Controlled Assembly and Disassembly of

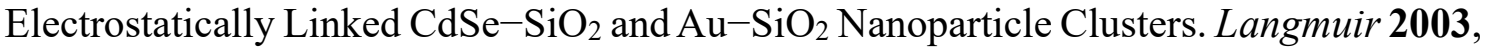
19, 7003-7011.

6 Stefano, C. D.; Giuffrè, O.; Sammartano, S. Protonation Constants of Ethylenediamine, Diethylenetriamine, and Spermine in $\mathrm{NaCl}(\mathrm{aq}), \mathrm{NaI}(\mathrm{aq}),\left(\mathrm{CH}_{3}\right)_{4} \mathrm{NCl}(\mathrm{aq})$, and $\left(\mathrm{C}_{2} \mathrm{H}_{5}\right) 4 \mathrm{NI}(\mathrm{aq})$ at Different Ionic Strengths and $t=25^{\circ} \mathrm{C}$. J. Chem. Eng. Data 2005, 50, 1917-1923.

7 Wang, P.; Fei, Y.; Deng, Y. Transformation of $\mathrm{CO}_{2}$ into Polyureas with 3-Amino-1,2,4triazole Potassium as a Solid Base Catalyst. New J. Chem. 2018, 42, 1202-1207.

${ }^{8}$ Frenna, V.; Vivona, N.; Consiglio, G.; Spinelli, D. Amine Basicities in Benzene and in Water. J. Chem. Soc., Perkin Trans. 2 1985, 1865-1868.

9 Stefano, C. D.; Giuffrè, O.; Sammartano, S. Thermodynamic Parameters for the Binding of ATP by Protonated Open-Chain Polyamines. J. Chem. Soc., Faraday Trans. 1998, 94, 1091-1095.

10 Kubo, Y.; Ishida, T.; Minami, T.; James, T. D. Highly Selective Fluoride Ion Detection Based on a Fluorescent Alizarin-o-Aminomethylphenylboronic Acid Ensemble in Aqueous MeOH Solution. Chem. Lett. 2006, 35, 996-997.

11 Miller, J. N.; Miller, J. C. Statistics and Chemometrics for Analytical Chemistry, 6th ed.; Pearson, 2010. 